\title{
, \\ Influence of Hot Water and 1-Methylcyclopropane Treatments on Air-Stored Quince Fruit
}

\author{
Nurdan Tuna Gunes $1, * \mathbb{C}$ and Ender Sinan Poyrazoğlu ${ }^{2}$ \\ 1 Department of Horticulture, Faculty of Agriculture, Ankara University, Ankara 06110, Turkey \\ 2 Department of Food Engineering, Faculty of Engineering and Architecture, Siirt University, \\ Siirt 56100, Turkey; poyrazoglu@siirt.edu.tr \\ * Correspondence: tuna@agri.ankara.edu.tr; Tel.: +90-312-596-13-20
}

check for updates

Citation: Gunes, N.T.; Poyrazoğlu, E.S. Influence of Hot Water and 1-Methylcyclopropane Treatments on Air-Stored Quince Fruit. Agronomy 2022, 12, 458. https://doi.org/ 10.3390/agronomy12020458

Academic Editors: Elazar Fallik and Zoran Ilic

Received: 11 December 2021 Accepted: 10 February 2022 Published: 12 February 2022

Publisher's Note: MDPI stays neutral with regard to jurisdictional claims in published maps and institutional affiliations.

Copyright: (C) 2022 by the authors. Licensee MDPI, Basel, Switzerland. This article is an open access article distributed under the terms and conditions of the Creative Commons Attribution (CC BY) license (https:// creativecommons.org/licenses/by/ $4.0 /)$.

\begin{abstract}
The commercial application potential of hot water treatments against 1-Methylcyclopropane (1-MCP) treatments for maintaining quality of fruit in quince (Cydonia oblonga Mill. cv. 'Eşme') during long-term regular air storage was investigated. The fruits were treated with either hot water at $50 \pm 1{ }^{\circ} \mathrm{C}$ for 3 and $5 \mathrm{~min}$ or two different 1-MCP (SmartFresh ${ }^{\mathrm{SM}}$ ) concentrations (300 ppb and $1000 \mathrm{ppb}$ ) at $12{ }^{\circ} \mathrm{C}$ for $20 \mathrm{~h}$. Then, all fruits were stored at $0 \pm 1{ }^{\circ} \mathrm{C}$ temperature, $85-90 \%$ relative humidity and regular air conditioning for 6 months. The efficacy of postharvest treatments in some fruit treats was monitored at monthly intervals. Postharvest treatments did not remarkably affect physiological features of fruits, such as ethylene production and respiration rate. Hot water treatments and 1000 ppb 1-MCP treatments positively maintained flesh color, acidity, malic acid content, 5-caffeoylquinic acid and vitamin C levels, and alleviated flesh firmness and sensory expert analysis scores. Overall, hot water treatment, a non-chemical treatment, had a potential for maintaining quality in quince fruit during long-term regular air storage at $0 \pm 1{ }^{\circ} \mathrm{C}$ temperature and $85-90 \%$ relative humidity conditions for 6 months.
\end{abstract}

Keywords: Cydonia oblonga Mill.; storage; quality; ascorbic acid; flesh browning; color

\section{Introduction}

Quince, Cydonia oblonga Mill., is one of the pome fruit species in the Rosaceae family. Its production around the world is much lower than other major species, such as apple and pear. However, global quince production has increased 1.3 times in the last decade and reached approximately 666,000 tons in 2019 thanks to main producers, e.g., Türkiye (27.1\%), China (18.8\%), Uzbekistan (12.7\%) and Islamic Republic of Iran (12.2\%) [1]. One of the reasons for this increase is a rise in awareness among consumers of health-protective effects of the quince fruit. It possesses anti-inflammatory, antimicrobial, anti-cancer, antiallergic, antioxidant and antiulcerogenic effects on human health [2] because of healthpromoting compounds and natural antioxidants at remarkable levels in the fruit [3]. The fruit principally includes malic, citric, ascorbic, quinic, shikimic and fumaric acids $[4,5]$, and high levels of pectin [6]. Fruit peel contains high levels of total amino acids and glycine, aspartic acid, asparagine and hydroxyproline [7], high levels of 3-caffeoylquinic acid and 5-caffeoylquinic acid, and polymeric procyanidins $[8,9]$.

Since high astringency level and hard fruit structure limit fresh consumption of this fruit, today, it can be widely consumed as processed food, e.g., jam or marmalade. The heat treatments employed during the processing of the fruit into value-added products result in a decrease in its health benefit characteristics [10], proving that consumption of fresh quince fruit is advisable to obtain the maximum benefit from health-promoting compounds. The harvest period for quince fruit coincides with the beginning of October in the northern hemisphere and, therefore, the fruits are available in the market for fresh consumption throughout the winter [11,12]. 
The storage period for quince fruit can vary from 2 months to 6 months at 0 or $2{ }^{\circ} \mathrm{C}$ temperature and regular air conditions. However, controlled atmosphere storage $\left(2 \mathrm{kPa} \mathrm{O}_{2}+3 \mathrm{kPa} \mathrm{CO}_{2}\right)$ at $2{ }^{\circ} \mathrm{C}$ temperature helps to extend this period up to 7 months [13]. The most liming factor in storage period is flesh browning incidence, which can cause vast amount of product loss in some years.

As in other pome fruit species, the application of appropriate postharvest handling and management techniques, as well as cold storage conditions, storage duration and maintaining fruit quality are essential for producing quince fruit with higher nutritional value to consumers. Today, there are many postharvest technologies that help not only in maintaining the quality of fresh horticultural products during cold storage and marketing period, but also in preventing the loss in nutritional value and product quantity caused by physiological or pathological reasons [14]. Plant growth regulators have been widely used for maintaining postharvest fruit quality in recent years. After the revelation of the retardant efficacy of cyclopropenes on the ripening and senescence of horticultural crops [15], in 2002, US EPA [16] approved 1-Methylcyclopropane (1-MCP) for use in edible food products, as there were no great adverse and toxicological effects detected in the mammalian and natural environment. However, it was registered as a biopesticide or plant growth regulator. Studies on more than 80 species, including quince [17-20], reported that gaseous 1-MCP acted as an efficient and powerful ripening retardant, and it maintained fruit quality. However, this effect depends on many factors, e.g., species and/or cultivar, treatment concentration, as well as the time between 1-MCP treatment and harvest, ecology and storage temperature. Today, it is used extensively for maintaining fruit quality during postharvest and marketing period in most climacteric fruit species, e.g., apple, kiwifruit, pear, tomato [20].

The harmful effects of chemicals on the environment and human health, as well as strict policies on residue levels in horticultural crops, have both canalized the consumers to avoid chemical-treated products and forced the researchers to develop new postharvest technologies free from chemicals in recent years. One such technology is heat treatments that can be applied as hot air, hot vapor and hot water. Studies showed that heat treatments can alleviate chilling injury, prolong the marketing period of a product at $20{ }^{\circ} \mathrm{C}$ and enhance not only several ripening-related features but also resistance to fungal diseases and physiological disorders in some horticultural species [21,22].

Studies on chemical-free postharvest technologies in quince fruit are limited to edible coatings, Semperfresh ${ }^{\mathrm{TM}}$, ascorbic acid [23] and gamma irradiation [24] treatments. Due to a lack of knowledge on the efficacy of heat treatments in maintaining quality in quince fruit during a long-term cold storage period, we constructed this experiment comparatively with gaseous 1-MCP treatments. Finally, the present study characterizes the influence of hot water treatments and 1-MCP treatments on some fruit features during a cold storage period of 6 months at $0 \pm 1{ }^{\circ} \mathrm{C}$ temperature, $85-90 \%$ relative humidity and regular air conditions.

\section{Materials and Methods}

\subsection{Plant Material and Harvest}

This study was conducted in Faculty of Agriculture, Ankara University $\left(39^{\circ} 95^{\prime} \mathrm{E}\right.$, $32^{\circ} 86^{\prime} \mathrm{N}$, altitude $857 \mathrm{~m}$ ). The fruits of the 'Eşme' cultivar were manually harvested at commercial harvest time, based on fruit color, firmness and soluble solids content [11]. The average data at harvest time were $104.50^{\circ}, 13.9 \%$ and $44.52 \mathrm{~N}$ for fruit peel hue value, soluble solids content and flesh firmness, respectively.

\subsection{Postharvest Treatments and Storage Conditions}

After the harvest, experimentally suitable, damage-free and uniform fruits, in terms of size, were selected and then randomly divided into 5 groups. Each group included 250 fruits. The first and second groups were treated with hot water at $50 \pm 1{ }^{\circ} \mathrm{C}$ by dipping for $3 \mathrm{~min}$ (HT-1) and $5 \mathrm{~min}$ (HT-2), respectively, and were transferred to cold storage after drying under ambient air circulation for $3 \mathrm{~h}$. The third and fourth groups were transferred 
to a storage room having $12{ }^{\circ} \mathrm{C}$ storage temperature for overnight cooling and were then treated with 1-MCP (SmartFresh ${ }^{\text {SM }}$, Agrofresh Inc., İstanbul, Türkiye) at 300 ppb (1-MCP-1) and $1000 \mathrm{ppb}(1-\mathrm{MCP}-2)$ concentrations, respectively. 1-MCP treatments at two different concentrations were performed separately in a gas-tight and sealed atmosphere of $1 \mathrm{~m}^{3}$ volume for $20 \mathrm{~h}$ at $12^{\circ} \mathrm{C}$ temperature in a cold storage room.

After treatment, all replications in groups were separately placed into perforated plastic crates with product capacity of $24 \mathrm{~kg}$. Then, they were stored at $0 \pm 1{ }^{\circ} \mathrm{C}$ temperature and $85-90 \%$ relative humidity under regular air conditions for 6 months.

The last group formed the controls, which were stored directly after harvest, without postharvest treatments.

\subsection{Assessments}

\subsubsection{Ethylene Production and Respiration Rate}

Five fruits per replication were kept in a $3.2 \mathrm{~L}$-sealed glass jar at $20 \pm 1{ }^{\circ} \mathrm{C}$ for $1 \mathrm{~h}$, and ethylene production was determined in $1 \mathrm{~mL}$ headspace gas sample by a gas chromatograph (Thermo Quest 2000, Rodano, MI, Italy) equipped with a flame ionization detector and an activated alumina stainless steel column (1 m, 80/100 mesh, Supelco 120-99) [25]. The oven, injector and detector temperatures of the gas chromatograph were $100^{\circ} \mathrm{C}, 100{ }^{\circ} \mathrm{C}$ and $120^{\circ} \mathrm{C}$, respectively. The results were calculated using external ethylene standard at $10 \mathrm{ppm}$ concentration (Alltech, Alltech Associates, Inc., Deerfield, IL, USA) and were expressed as pmol $\mathrm{C}_{2} \mathrm{H}_{4} \cdot \mathrm{kg}^{-1} \cdot \mathrm{h}^{-1}$ [26]. Respiration rate was determined in the same headspace gas samples by monitoring $\mathrm{CO}_{2}$ concentration with an infrared $\mathrm{CO}_{2}$ analyzer (Servomex PA 404, Crowborough, Sussex, UK). The results were expressed in $\mathrm{mL} \mathrm{CO} 2 \cdot \mathrm{kg}^{-1} \cdot \mathrm{h}^{-1}$ [25].

\subsubsection{Fruit Peel and Flesh Color}

Color analyses were performed on 10 fruits per replication. Peel color was determined at 3 different points on the equatorial region of fruit. Flesh color was measured at 3 different points on the fruits' lateral cutting surface. The average value of 3 different measurements formed the color value of a fruit. All measurements were recorded using a colorimeter (CR-200 Minolta, Tokyo, Japan) in CIE $L^{*} a^{*} b^{*}$ color system. Data were presented as $L^{*}$ (lightness) and hue $\left(\mathrm{h}^{\circ}\right)$ values [27].

\subsubsection{Flesh Browning Rate}

More than $25 \%$ browning on the longitudinal cutting surface area of the fruit was considered flesh browning, as in a previous study [28]. The number of fruits with flesh browning per replication was rated with total fruit number, and the results were expressed as a percentage of total fruit number.

\subsubsection{Flesh Firmness}

A texture analyzer (TA XT-Plus, Stable Microsystems, Godalming, Surrey GU7 1YL, UK) occupied by a stainless steel probe in $5 \mathrm{~mm}$ diameter and a penetration test were used to determine flesh firmness. Measurements were recorded on the equatorial region at 3 different points of 10 fruits per replication. Test speed, trigger force and final depth of the probe in the cortex tissue were applied as $1 \mathrm{~mm} \cdot \mathrm{s}^{-1}, 5 \mathrm{~g}$ and $10 \mathrm{~mm}$, respectively. The load cell capacity of the instrument was $50 \mathrm{~kg}$. Data were extracted from the curve set by Texture Exponent software (Version 6, Stable Microsystems, Godalming, Surrey GU7 1YL, UK) during texture analyses [29].

\subsubsection{Soluble Solids Content and Titratable Acidity}

A digital Abbe refractometer (Leica 10480, Wertheim, Germany) measured soluble solids content in squeezed and filtered fruit juice extracted from 10 fruits per replication. Titratable acidity was determined by end-point titration of eluted fruit juice with $0.1 \mathrm{~N}$ sodium hydroxide until reaching $\mathrm{pH}=8.1$ with an automatic titrator (Mettler Toledo, DL 50). The results were presented as a percentage of malic acid. 


\subsubsection{Weight Loss}

Ten fruits per replication were randomly selected and marked for weight loss determination at the beginning of the storage period. The weight of each fruit was recorded on each sampling day at monthly intervals. The weight loss was specified on the basis of initial weight and subsequent weight loss that occurred during the storage period at monthly intervals. The results were expressed as a percentage of initial fresh weight.

\subsubsection{Sensory Expert Analyses}

Eight trained panelists conducted sensory expert analyses in terms of fruit appearance, sweetness, sourness, astringency, aroma and general acceptability on a scale of 1 (unacceptable) and 5 (excellent) points [30]. Fruit slices with peel of $1 \mathrm{~cm}$ in thickness were served with water and unsalted bread to the panelists during analyses.

\subsubsection{Sugars, Organic Acids, Phenolic Compounds and Vitamin C}

Sugars, organic acids, phenolic compounds and vitamin $\mathrm{C}$ were studied by a highperformance liquid chromatograph (HPLC) (Shimadzu, LC 10AT-VP, Kyoto, Japan). For these analyses, two fruit slices from each fruit per replication were frozen as soon as possible after sampling and were kept at $-80^{\circ} \mathrm{C}$ until the analyzing stage. All chromatographic analyses were performed on grounded samples. Around $10 \mathrm{~g}$ sample was homogenized with $20 \mathrm{~mL}$ ultra-pure water on ice by a homogenizer (Ultraturrax 725) for $1 \mathrm{~min}$ at $2400 \mathrm{rpm} \cdot \mathrm{min}^{-1}$ for sugar and organic acid extractions. The supernatant of $2 \mathrm{~mL}$ was filtered through a membrane filter (Millipore, HVLP $04700,0.45 \mu \mathrm{m}$ pore size) in glass vials (Aim, SV-15B) after centrifugation at $15,000 \mathrm{rpm} \cdot \mathrm{min}^{-1}$ at $1^{\circ} \mathrm{C}$ for $30 \mathrm{~min}$ [31]. Samples at $20 \mu \mathrm{L}$ volume were injected to the instrument via an auto sampler. Sugars were eluted by Nucleogel Sugar 810 Ca column $(300 \times 7.8 \mathrm{~mm}, 8-10 \mu \mathrm{m}$, Machenery Nagel $)$ at an oven temperature of $80^{\circ} \mathrm{C}$ using ultra-pure water as eluent. Refractive index detector (Shimadzu, RID 10A) identified and quantitated individual sugars.

The organic acids were extracted from a $5 \mathrm{~mL}$ supernatant after eliminating phenolic compounds through $C_{18}$ Sep Pak ${ }^{\circledR}$ cartridges (55-105 $\mu \mathrm{m}, 300 \mathrm{mg}$, Alltech ${ }^{\circledR}$, Maxi clean, Deerfield, IL, USA) that were conditioned earlier with $1.5 \mathrm{~mL}$ methanol (HPLC grade, Merck, Dramstadt, Germany) and $1.5 \mathrm{~mL} 0.05$ N sulfuric acid (95-98\%, Merck, Dramstadt, Germany) at a flow rate of $0.1 \mathrm{~mL} \cdot \mathrm{s}^{-1}$ [32]. An Aminex HPX-87H column $(300 \times 7.8 \mathrm{~mm}$, $9 \mu \mathrm{m}$, Bio-Rad Laboratories, Inc., California, CA, USA ) enabled a separation of organic acids at an oven temperature of $25^{\circ} \mathrm{C}$, and the eluent was $5 \mathrm{mM}$ sulfuric acid at a flow rate of $0.6 \mathrm{~mL} \cdot \mathrm{min}^{-1}$. Absorbance values were recorded via diode array detector (Shimadzu SPD $\mathrm{m} \mathrm{10AVP)}$ ) at $210 \mathrm{~nm}$ wavelength [31].

The phenolic compounds were extracted two times via $\mathrm{C}_{18}$ solid phase extraction cartridges (Agilent Technology, Santa Clara, CA, USA) under vacuum into $1.5 \mathrm{~mL}$ methanol. Around $10 \mathrm{~g}$ grounded sample was homogenized with $20 \mathrm{~mL}$ ultra-pure water on ice by a homogenizer (Ultraturrax 725) for $1 \mathrm{~min}$ at $2400 \mathrm{rpm} \cdot \mathrm{min}^{-1}$ and was centrifuged at $15,000 \mathrm{rpm} \cdot \mathrm{min}^{-1}$ at $1{ }^{\circ} \mathrm{C}$ for $30 \mathrm{~min}$. The supernatant was uploaded on solid phase extraction cartridges previously activated with $5 \mathrm{~mL}$ methanol and then $1.5 \mathrm{~mL} 0.05 \mathrm{~N}$ sulfuric acid (95-98\%, Merck, Dramstadt, Germany). The retained phenolic fraction was eluted with $2 \mathrm{~mL}$ methanol into the vials. The chromatographic separation was performed on the $\mathrm{ODS}_{2}$ column (Technochroma, Tracer Extrasil, $5 \mu \mathrm{m}, 250 \times 4.6 \mathrm{~mm}$ ) using two solvents (A: $0.1 \%$ phosphoric acid $(v / v)$ and B: acetonitrile with phosphoric acid at $0.1 \%$ $(v / v))$ under gradient conditions at a flow rate of $1 \mathrm{~mL} \cdot \mathrm{min}^{-1}$. The oven temperature was $40^{\circ} \mathrm{C}$ [9]. The diode array detector (Shimadzu SPD m 10AVP) read the absorbance values at $280 \mathrm{~nm}$ and $325 \mathrm{~nm}$ wavelengths.

Vitamin $\mathrm{C}$ was extracted from $5 \mathrm{~g}$ frozen sample via a homogenization procedure with $10 \mathrm{~mL} 6 \%(v / v)$ metaphosphoric acid (Sigma-Aldrich, Darmstadt, Germany) on ice for $15 \mathrm{~s}$ at $2400 \mathrm{rpm} \cdot \mathrm{min}^{-1}$ (Ultraturrax 725) and then a centrifugation procedure at $1{ }^{\circ} \mathrm{C}$ at $14,000 \mathrm{rpm} \cdot \mathrm{min}^{-1}$ for $10 \mathrm{~min}$ [33]. Eventually, the extract was filtered through a $0.45 \mu \mathrm{m}$ filter (Millipore, HVLP 04700) and collected in amber-colored vials (Aim, SV-15A). Luna 
$\mathrm{C}_{18}$ (Phenomenex, $250 \times 4.60 \mathrm{~mm}, 5 \mu$ ) column separated vitamin $\mathrm{C}$ at $25^{\circ} \mathrm{C}$ by an elution buffer, ultra-pure water $(\mathrm{pH}=2.2)$ at a flow rate of $1 \mathrm{~mL} \cdot \mathrm{min}^{-1}$. The absorbance values at $250 \mathrm{~nm}$ wavelength were read by diode array detector (Shimadzu SPD m 10AVP).

All identifications and quantifications were performed by external standard solutions of pure chemicals purchased from Sigma-Aldrich (Darmstadt, Germany).

\subsection{Experimental Design and Statistical Evaluations}

The experiment was set in a completely randomized design with 3 replications and conducted over 2 subsequent years to observe reproducible results of postharvest treatments in different years. Each treatment contained 3 replications, and each replication included 10 fruits. Changes in some fruit traits was monitored at monthly intervals during the cold storage period of 6 months. Arcsine transformations were applied to data in percentages, e.g., data of weight loss and flesh browning, before statistical evaluation. Analysis of variance (ANOVA) was performed on the data by using Minitab statistical software (trial version). Postharvest treatments, e.g., hot water treatments and 1-MCP treatments, and storage period of 6 months, were considered as independent variables. The fruit traits investigated in the current study formed dependent variables. Differences at $p \leq 0.05$ significance level were significant. Tukey test compared the mean values at $p \leq 0.05$ significance level.

\section{Results and Discussion}

\subsection{Ethylene Production and Respiration Rate}

Storage period and treatments interactively affected ethylene production in quince fruit in both years $(p \leq 0.05)$ (Table 1$)$. It gradually increased in controls until the end of the second month, and lower values were determined in the fourth and fifth months in both years (Figure 1a). A decreasing trend occurred after the third month in the first year, but a clear increase was observed at the end of the sixth month in the second year.

Even if $1000 \mathrm{ppb}$ 1-methylcyclopropane (1-MCP)-treated fruit on average exhibited lower ethylene production $\left(167.67 \mathrm{pmol} \mathrm{C}_{2} \mathrm{H}_{4} \cdot \mathrm{kg}^{-1} \cdot \mathrm{s}^{-1}\right.$ in the first and $152.38 \mathrm{pmol}$ $\mathrm{C}_{2} \mathrm{H}_{4} \cdot \mathrm{kg}^{-1} \cdot \mathrm{s}^{-1}$ in the second year, respectively) in both years, and ethylene production was at least 0.9 times higher in controls, the differences among treatments were not significant $(p>0.05)$. However, during the earlier storage period, including after treatments, an observation of lower ethylene production in 1-MCP-2 and HT-2-treated group in both years can show that quince fruit may regain its ripening capability by prolonging the storage period. Moreover, the slowing-down effect of the aforementioned treatments on ethylene production is limited to the short storage period.

In both years, the storage period and treatments interactively affected the respiration rate of quince fruit (Table 1, Figure $1 \mathrm{~b}$ ). Generally, this parameter gradually decreased up to the end of the fourth month in all groups and then increased along with the rest of the storage period. In both years, the respiration rate values at the beginning and the end of the storage period were similar. The effect of treatments on the respiration rate was significant only in the second year $(p \geq 0.05)$, resulting in the lowest respiration rate in HT-2 (4.35 mL $\left.\mathrm{CO}_{2} \cdot \mathrm{kg}^{-1} \cdot \mathrm{h}^{-1}\right)$ and 1-MCP-2 $\left(4.38 \mathrm{~mL} \mathrm{CO} \cdot \mathrm{kg}^{-1} \cdot \mathrm{h}^{-1}\right)$ groups (Figure $\left.1 \mathrm{~b}\right)$.

Today, it is widely known that $1-\mathrm{MCP}$ can prolong the ripening period in climacteric fruit species by delaying ethylene perception and production, and by inhibiting the respiration rate during storage period due to prevention of the binding of ethylene to the cellular receptors [20]. However, studies on the efficacy of 1-MCP on ethylene production and respiration rate in quince fruit reported contrasting results. Gunes [17] reported the inhibitory effect of $625 \mathrm{ppb} 1-\mathrm{MCP}$ on ethylene production and respiration rate in the 'Eşme' cultivar, while unremarkable efficacy of 1-MCP on the same cultivar was pointed out in another study [34]. The efficacy of 1-MCP depends on some other factors, e.g., application concentration, the time between application and harvest, harvest maturity of the fruit [20], and these factors could play a role in the contrasting results obtained in previous studies. 
Table 1. Significance of influence $(p)$ of storage period and different postharvest treatments on some traits of quince fruit.

\begin{tabular}{|c|c|c|c|c|c|c|}
\hline \multirow{3}{*}{ Assessments } & \multicolumn{6}{|c|}{ Source of Variation } \\
\hline & \multicolumn{3}{|c|}{ First Year } & \multicolumn{3}{|c|}{ Second Year } \\
\hline & $\mathrm{SP}^{1}$ & Ts ${ }^{1}$ & $\mathrm{SP} \times \mathrm{Ts}^{1}$ & SP & Ts & $\mathbf{S P} \times \mathbf{T s}$ \\
\hline Ethylene production & $* * *$ & $\mathrm{~ns}^{2}$ & $* *$ & $* * *$ & ns & $* *$ \\
\hline Respiration rate & $* * *$ & ns & $* *$ & $* * *$ & $* * *$ & $* * *$ \\
\hline Peel hue & $* * *$ & $* * *$ & $* *$ & $* * *$ & ns & ns \\
\hline Peel L* & $* * *$ & ns & ns & $* * *$ & ns & ns \\
\hline Flesh hue & $* * *$ & $* * *$ & $* *$ & $* * *$ & $* * *$ & ns \\
\hline Flesh $\mathrm{L}^{*}$ & $* * *$ & * & $* * *$ & $* * *$ & $* *$ & ns \\
\hline Flesh browning rate & $* * *$ & $* * *$ & $* * *$ & $* * *$ & $* * *$ & $* * *$ \\
\hline Flesh firmness & $* * *$ & $* * *$ & $* * *$ & $* * *$ & $* * *$ & $* *$ \\
\hline Soluble solids & ns & ns & ns & $* * *$ & $* *$ & ns \\
\hline Titratable acidity & $* * *$ & $* *$ & $* * *$ & $* * *$ & $* *$ & ns \\
\hline Weight loss & $* * *$ & $* * *$ & $* * *$ & $* * *$ & $* * *$ & $* * *$ \\
\hline Sensory expert analyses & $* * *$ & $* * *$ & $* * *$ & $* * *$ & $* * *$ & $* * *$ \\
\hline Vitamin C & $* * *$ & * & * & $* * *$ & $* *$ & ns \\
\hline
\end{tabular}

${ }^{1} \mathrm{SP}$-storage period, harvest +6 months; Ts-treatments, hot water treatments at $50 \pm 1{ }^{\circ} \mathrm{C}$ temperature for $3 \mathrm{~min}$ and $5 \mathrm{~min}, 1$-methylcyclopropane (1-MCP) treatments at $300 \mathrm{ppb}$ and $1000 \mathrm{ppb}$ concentrations for $20 \mathrm{~h}$ at $12{ }^{\circ} \mathrm{C}$; ${ }^{2}$ ns-not significant at $p>0.05 ;{ }^{*}, * *$, and ${ }^{* * *}$, significant at $p \leq 0.05,0.01$, and 0.001 significance levels, respectively.

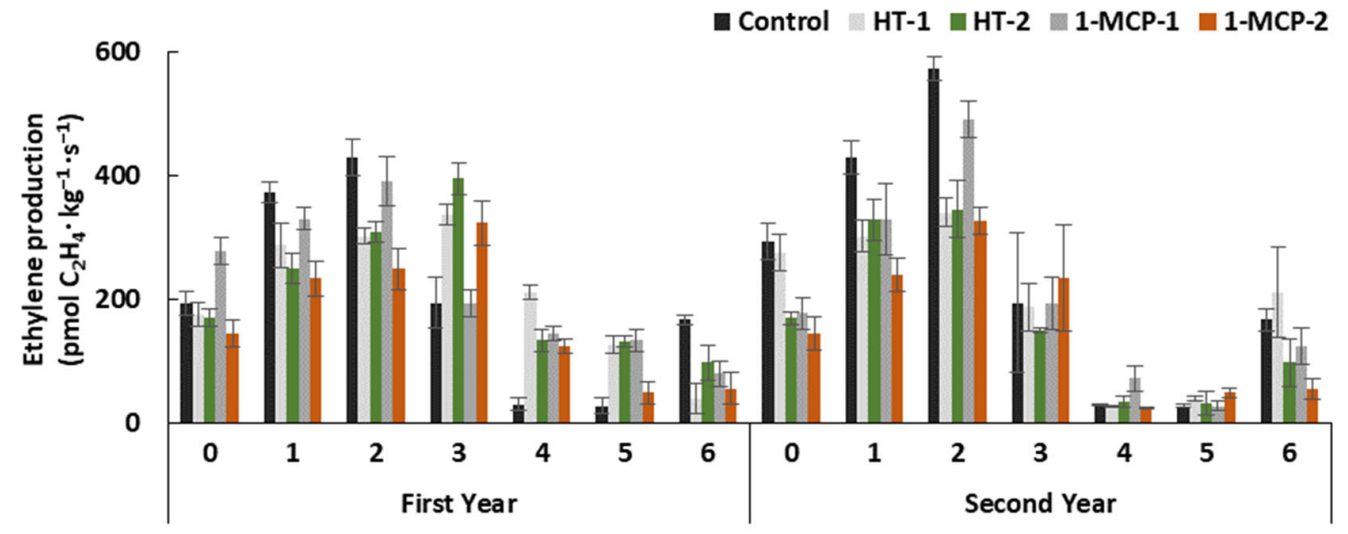

(a)

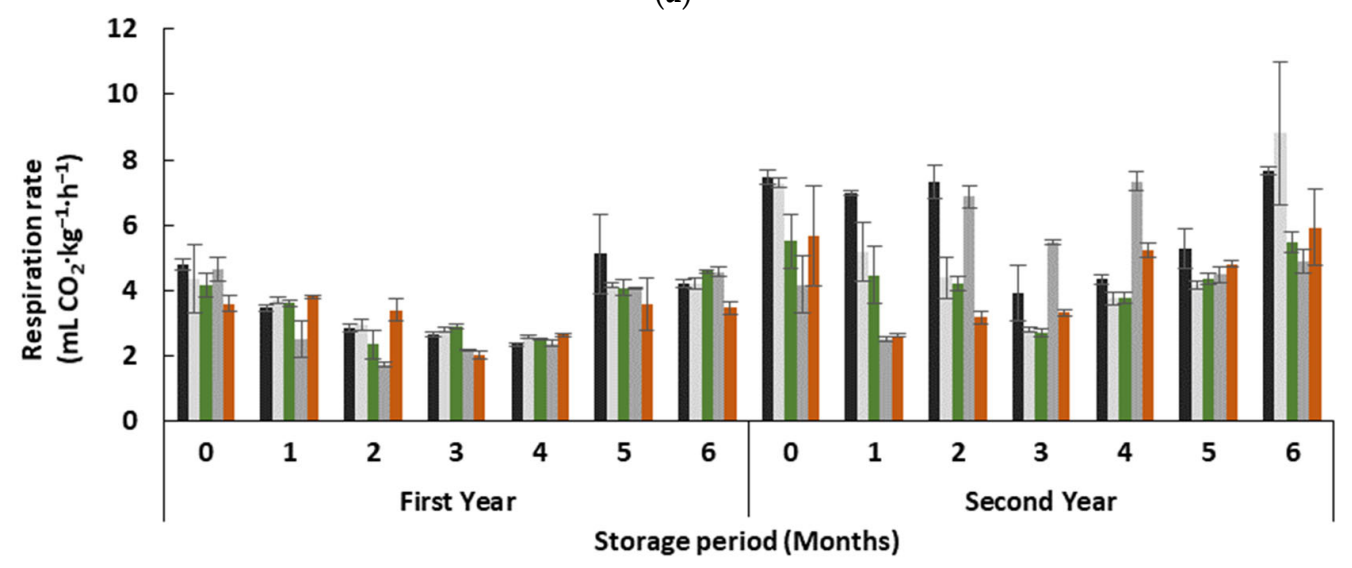

(b)

Figure 1. The effect of different postharvest treatments on ethylene production (a) and respiration rate (b) of the quince fruit during long-term cold storage period of 6 months at $0 \pm 1{ }^{\circ} \mathrm{C}, 85-90 \%$ relative humidity and regular air conditions. Control—without postharvest treatment; HT-1-Hot water treatment at $50 \pm 1{ }^{\circ} \mathrm{C}$ for $3 \mathrm{~min}$; HT-2-Hot water treatment at $50 \pm 1{ }^{\circ} \mathrm{C}$ for $5 \mathrm{~min}$; 1 -MCP1 -300 ppb 1-methylcyclopropane (1-MCP) treatment at $12{ }^{\circ} \mathrm{C}$ for $20 \mathrm{~h}$; 1-MCP-2-1000 ppb 1-MCP treatment at $12{ }^{\circ} \mathrm{C}$ for $20 \mathrm{~h}$. Vertical lines are the standard error of means. 
In this study, the inhibitory effect of hot water treatments was not significant on ethylene production of fruit in both years, but hot water treatment for 5 min (HT-2) caused a lower respiration rate in the second year. It has been reported that ethylene production and respiration rate were inhibited in apples as soon as after heat treatment, but the heattreated fruit regained its ethylene production ability during the rest of the storage period and produced higher levels of ethylene than controls [25]. In the current study, the recovery of ethylene production could be possible following heat treatments in heat-treated quince fruit as well.

\subsection{Fruit Peel, Flesh Color, Flesh Browning}

Peel hue values of fruit regularly decreased, and $L^{*}$ values increased during the entire storage period in both years $(p \leq 0.05)$ (Table 1 , Figure $2 a)$. Similar changes were reported in other studies conducted on quince fruit $[13,17,18,34-36]$. The postharvest treatments significantly affected peel hue values, which changed between $92.20^{\circ}$ (controls) and $98.08^{\circ}$ (1-MCP-2) only in the first year.

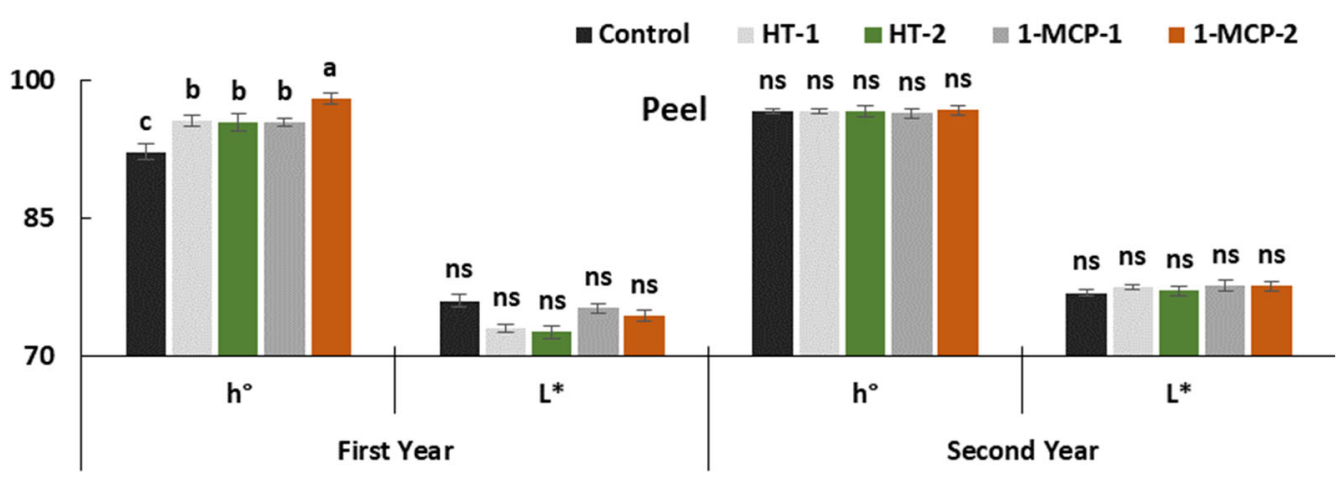

(a)

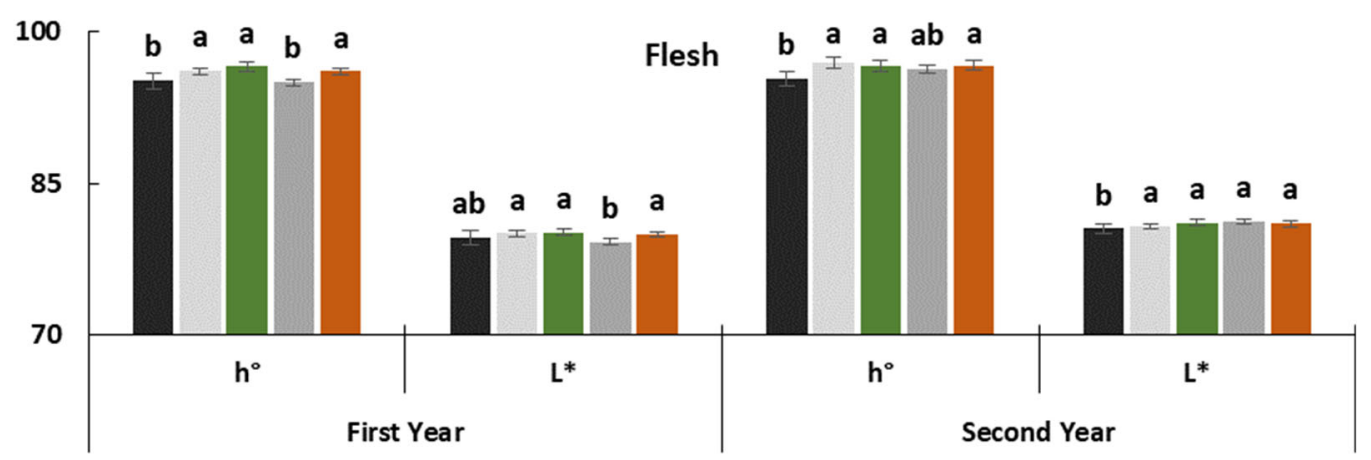

(b)

Figure 2. The effect of different postharvest treatments on peel (a) and flesh (b) color of quince fruit during long-term cold storage period of 6 months at $0 \pm 1{ }^{\circ} \mathrm{C}, 85-90 \%$ relative humidity and regular air conditions. Control—without postharvest treatment; HT-1-Hot water treatment at $50 \pm 1{ }^{\circ} \mathrm{C}$ for $3 \mathrm{~min}$; HT-2-Hot water treatment at $50 \pm 1{ }^{\circ} \mathrm{C}$ for $5 \mathrm{~min}$; 1-MCP-1-300 ppb 1-methylcyclopropane (1-MCP) treatment at $12{ }^{\circ} \mathrm{C}$ for $20 \mathrm{~h}$; 1 -MCP-2-1000 ppb 1-MCP treatment at $12{ }^{\circ} \mathrm{C}$ for $20 \mathrm{~h}$. Vertical lines are the standard error of means. Different letters are significantly different, according to Tukey test, at $p \leq 0.05$ significance level; ns-not significant at $p \leq 0.05$.

The higher hue values reflect color that is more greenish. Evidently, $1000 \mathrm{ppb} 1-\mathrm{MCP}$ treatment has effectively delayed chlorophyll degradation. The efficacy of HT-1 $\left(95.57^{\circ}\right)$, HT-2 $\left(95.43^{\circ}\right)$ and 1-MCP-1 $\left(95.44^{\circ}\right)$ treatments was lower than 1-MCP-2 in the first year. However, the effectiveness of treatments on color depended on experimental years. Maintained peel color in quince fruit by 1-MCP treatment was pointed out in previous studies $[17,34]$. In our study, the effects of heat treatments on hue values were better than the 
controls. Similar results were reported in pear fruit [31]. Quince fruit has a yellow peel color at the ripening stage, and the fruit with yellow peel color is the ideal product for the marketplace and for consumer demand. In this study, heat treatments helped to alleviate yellow peel color better than the 1-MCP-2 treatment.

The impact of postharvest treatments was clear on the flesh hue and $L^{*}$ values, which significantly decreased during the entire storage period in both years $(p \leq 0.05)$ (Table 1 , Figure $2 b$ ). These parameters were better kept with 1-MCP-2, HT-1 and HT-2 treatments in both years. Our findings on maintaining flesh color by 1-MCP treatment are similar to other studies on quince fruit $[17,19,34,35]$. In this context, both the 3 min hot water dipping (HT-1) and 5 min hot water dipping (HT-2) have had a positive effect that cannot be ignored on slowing down the decrease in flesh $L^{*}$ values.

Flesh browning disorder is the main problem in quince fruit during long-term storage period. It is a physiological disorder that is assumed to be a chilling injury because of a higher incidence at lower storage temperature. It negatively affects consumer preference as well. The flesh browning incidence in quince fruit occurring during the cold storage period depends on ecological conditions throughout the preharvest period [17] and on genotypes [37]. The genotypes with higher polyphenol oxidase and peroxidase activities, and with lower levels of ascorbic acid, total phenolics and total antioxidant activity in fruit tissue, exhibited hypersensitivity to flesh browning [37]. 1-MCP has a powerful effect in limiting flesh browning in quince fruit $[17,34,35,37]$. In our study, the storage period and postharvest treatments interacted with flesh browning in both years $(p \leq 0.05)$ (Table 1). Flesh browning incidence significantly increased during the time in storage in all groups. Its first appearance was at the end of the third month in HT-2 (3.3\%) and in $300 \mathrm{ppb} 1-\mathrm{MCP}$ $(5.0 \%)$-treated fruit in the first year, and in 1-MCP-1 (5.0\%) and 1-MCP-2 (2.0\%) groups in the second year, respectively (Table 1, Figure 3a). It was the worst at the end of the sixth month in both years.

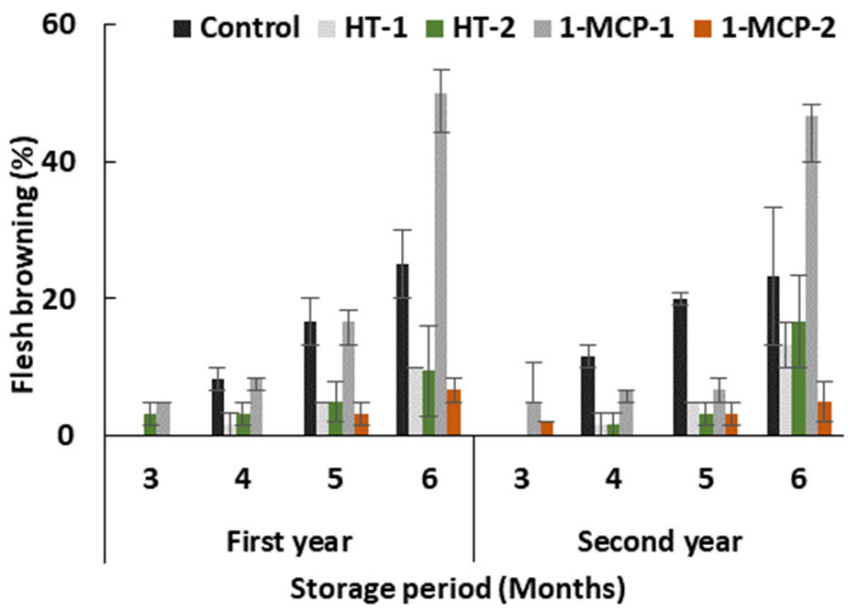

(a)

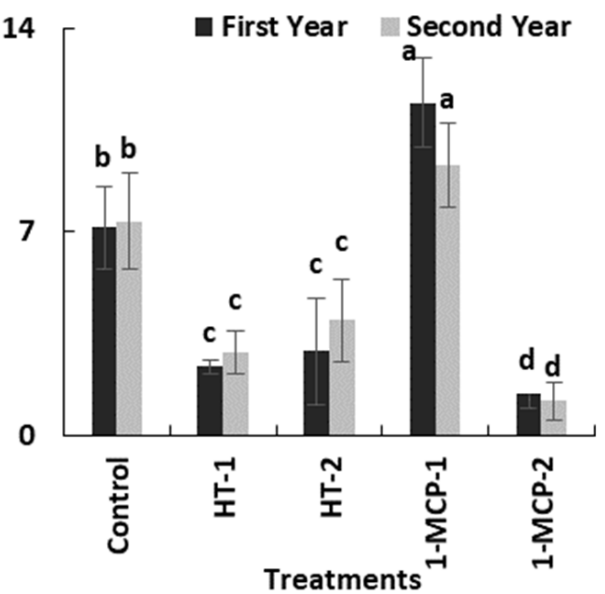

(b)

Figure 3. The effect of the storage period of 6 months at $0 \pm 1{ }^{\circ} \mathrm{C}$ temperature, $85-90 \%$ relative humidity and regular air conditions (a) and different postharvest treatments (b) on flesh browning incidence of quince fruit during long-term cold storage period. Control—without postharvest treatment; HT-1-Hot water treatment at $50 \pm 1^{\circ} \mathrm{C}$ for $3 \mathrm{~min}$; HT-2- Hot water treatment at $50 \pm 1{ }^{\circ} \mathrm{C}$ for $5 \mathrm{~min}$; 1-MCP-1-300 ppb 1-methylcyclopropane (1-MCP) treatment at $12{ }^{\circ} \mathrm{C}$ for $20 \mathrm{~h}$; 1 -MCP-2-1000 ppb 1 -MCP treatment at $12{ }^{\circ} \mathrm{C}$ for $20 \mathrm{~h}$. Vertical lines are the standard error of means. Different letters are significantly different, according to Tukey test, at $p \leq 0.05$ significance level.

Regarding average values, it is possible to see a significant effect of postharvest treatments. 1-MCP-2 (1.43\% and 1.19\%) treatment followed by HT-1 $(2.38 \%$ and $2.85 \%)$ and HT-2 $(2.90 \%$ and $3.95 \%)$ were promising treatments because of their considerable restrictive effect on disorder incidence in both years, respectively $(p \leq 0.05)$ (Figures $3 \mathrm{~b}$ and 4$)$. Our 
findings on $1000 \mathrm{ppb} 1-\mathrm{MCP}$ treatment are relevant to the previous works $[17,34,35]$. In the present study, an additional feature of note is that fruit susceptibility to flesh browning in 1-MCP-1 group is more than that of controls (Figures $3 \mathrm{~b}$ and $4 \mathrm{c}$ ) and, consequently, the lower 1-MCP dose seems to accelerate disorder incidence, while heat treatments offer a compromise on flesh browning risk in quince fruit. Heat treatments in horticultural products have been found in many cases to induce chilling tolerance [38], and this effect could be the main reason for lower disorder incidence in heat-treated fruit in our study. On the other hand, a previous study showed that higher temperature regimes and longer heat treatment period, e.g., $10 \mathrm{~min}$ at $60^{\circ} \mathrm{C}$, reversed this obstructive effect of heat treatment on flesh browning in quince fruit [39].

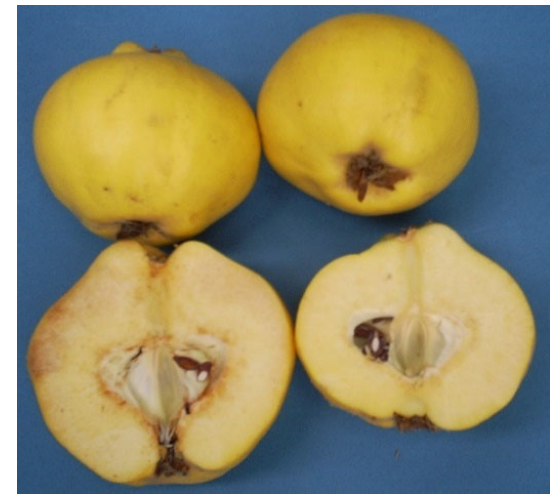

(a)

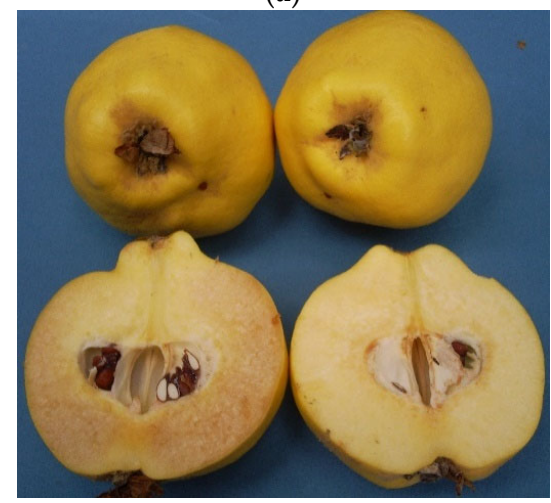

(c)

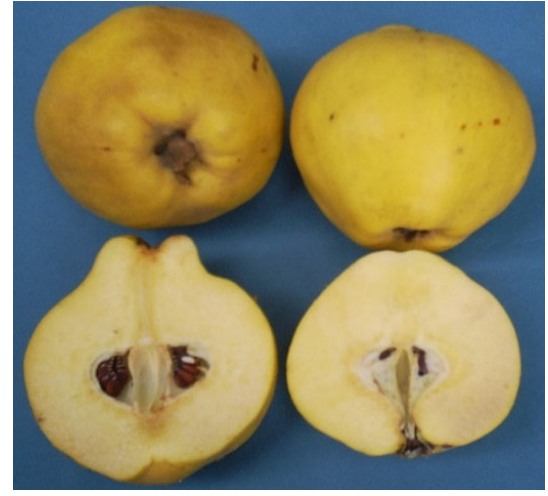

(b)

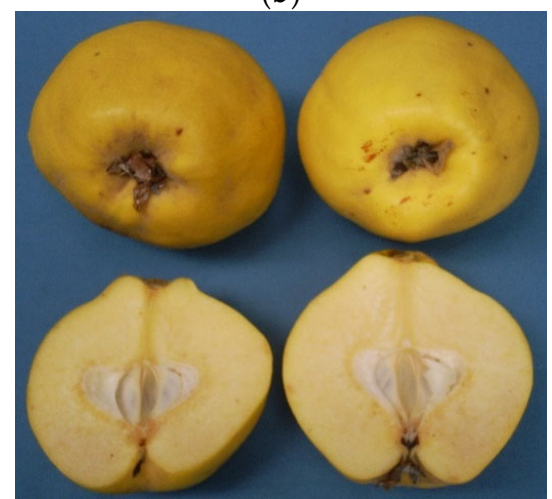

(d)

Figure 4. The appearance of quince fruit treated with different postharvest treatments after cold storage period of 6 months at $0 \pm 1{ }^{\circ} \mathrm{C}, 85-90 \%$ relative humidity and regular air conditions. (a) - Hot water treatment at $50 \pm 1{ }^{\circ} \mathrm{C}$ for $3 \mathrm{~min}$; (b) - Hot water treatment at $50 \pm 1{ }^{\circ} \mathrm{C}$ for $5 \mathrm{~min}$; (c) - $300 \mathrm{ppb}$ 1-methylcyclopropane (1-MCP) treatment at $12{ }^{\circ} \mathrm{C}$ for $20 \mathrm{~h}$; (d) - $1000 \mathrm{ppb} 1-\mathrm{MCP}$ treatment at $12{ }^{\circ} \mathrm{C}$ for $20 \mathrm{~h}$.

\subsection{Firmness, Soluble Solids Content and Titratable Acidity}

Flesh firmness and titratable acidity of quince fruit gradually decreased $(p \leq 0.05)$, while soluble solids content exhibited unstable changes in all treatments over the time in the storage period in both years (Table 1, Figure 5a,c,e), as in other reports $[17,18,36,40]$.

The softest fruits were controls, while the firmest fruits were in the 1-MCP-treated group in the first year. However, in the second year, the heat and 1-MCP treatments showed similar effects on the loss of firmness during the cold storage period and produced firmer fruits than controls (Figure 5b,d,f). The obstructive effect of 1-MCP-based technology on the loss of flesh firmness in climacteric fruit species, including quince fruit, was reported in other studies $[17,18,20,34,35]$. The effect of heat treatments may be via the inhibition of cell wall- or pectin-degrading enzyme activities and alteration in polygalacturonase activity due to changes in normal protein synthesis and cellular metabolism during heat stress $[21,22,39]$. 


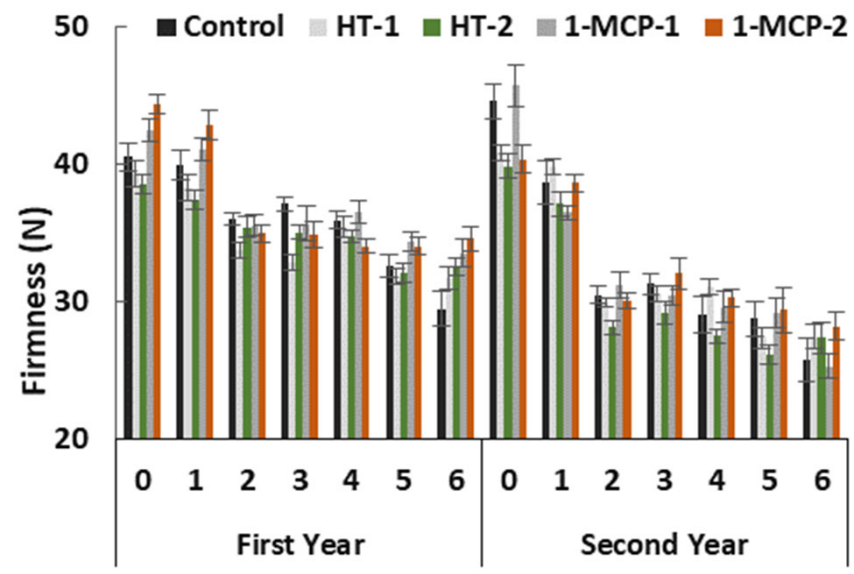

(a)

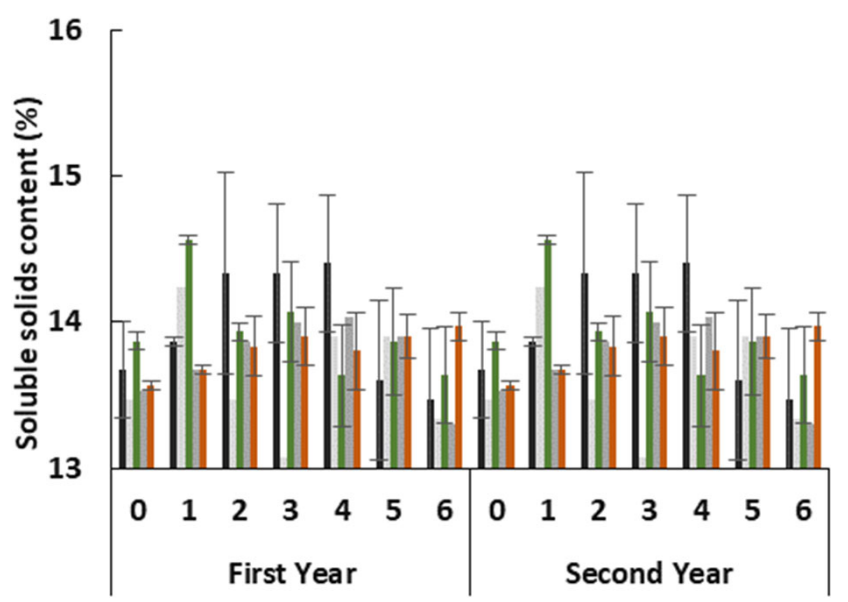

(c)

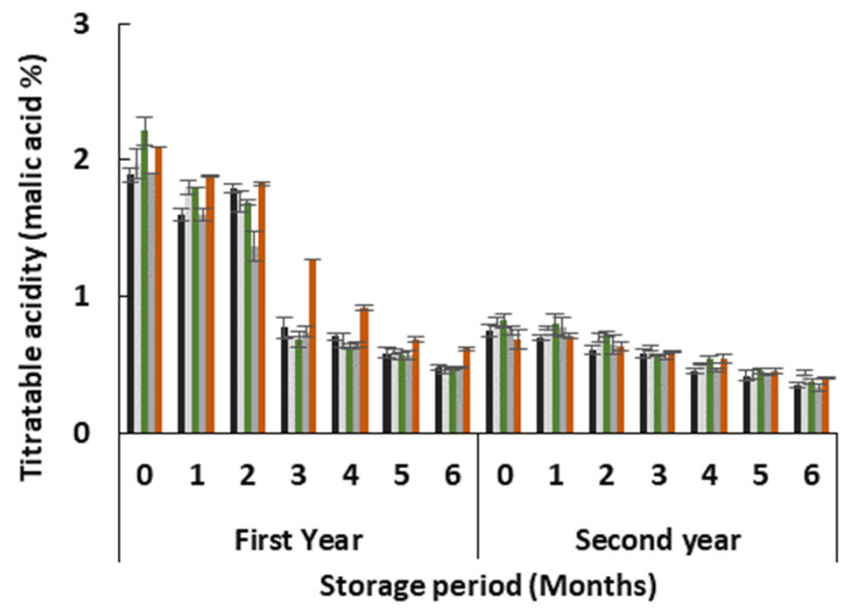

(e)

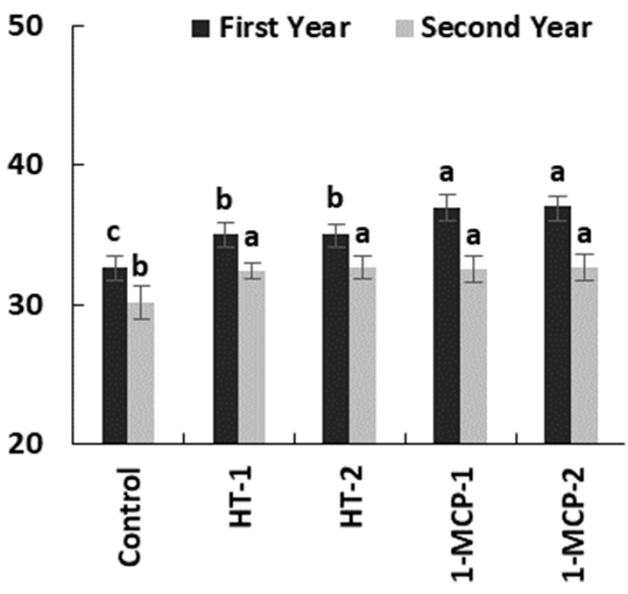

(b)

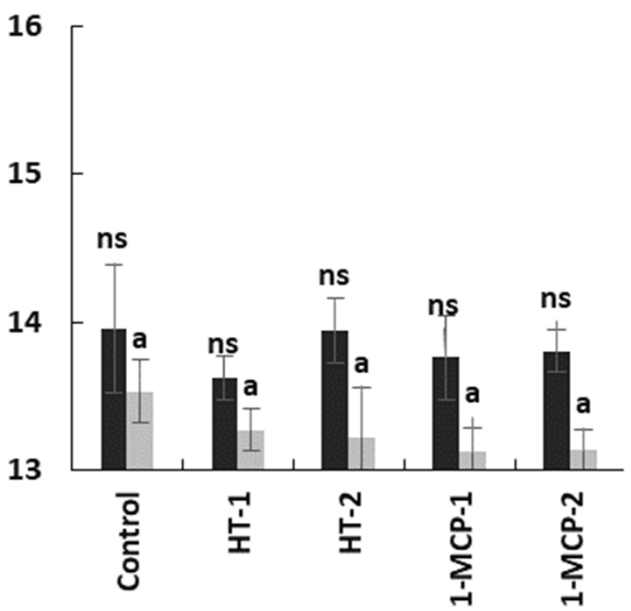

(d)

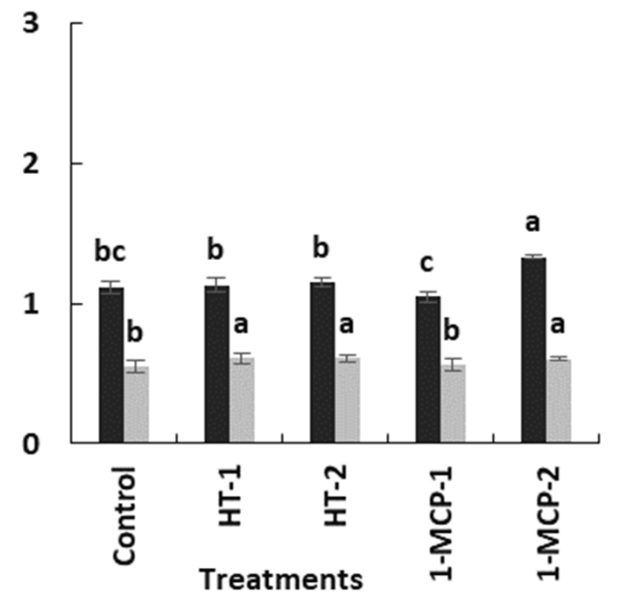

(f)

Figure 5. The effect of storage period of 6 months at $0 \pm 1{ }^{\circ} \mathrm{C}$ temperature, $85-90 \%$ relative humidity and regular air conditions $(\mathbf{a}, \mathbf{c}, \mathbf{e})$; and the effect of different postharvest treatments $(\mathbf{b}, \mathbf{d}, \mathbf{f})$ on flesh firmness, soluble solids content and titratable acidity of quince fruit during long-term cold storage. Control-without postharvest treatment; HT-1-Hot water treatment at $50 \pm 1{ }^{\circ} \mathrm{C}$ for 3 min; HT2-Hot water treatment at $50 \pm 1{ }^{\circ} \mathrm{C}$ for $5 \mathrm{~min}$; 1-MCP-1-300 ppb 1-methylcyclopropane (1-MCP) treatment at $12{ }^{\circ} \mathrm{C}$ for $20 \mathrm{~h}$; 1 -MCP-2-1000 ppb 1-MCP treatment at $12{ }^{\circ} \mathrm{C}$ for $20 \mathrm{~h}$. Vertical lines are the standard error of means. Different letters are significantly different, according to Tukey test, at $p \leq 0.05$ significance level; ns-not significant at $p>0.05$. 
Soluble solids content levels in quince fruit exhibited unstable changes during storage in both years $(p \leq 0.05)$ (Table 1 , Figure $5 c)$. However, the individual impact of postharvest treatments on soluble solids content was not satisfactory in terms of average values $(p>0.05)$ (Table 1, Figure 5d). The fact that the effect of HT-2 treatment led to the highest soluble solids content values at the end of the first month in both years can be interpreted as the stimulation of starch degradation (Figure $5 \mathrm{c}$ ). After the first month and following the next 3 months in both years, the controls exhibited the highest level of soluble solids content, and this situation can be regarded as evidence of earlier initiation of carbohydrate degradation in this group (Table 1, Figure 5c).

Organic acids, which form acidity in the fruit, mostly affect fruit taste and quality. Titratable acidity of quince fruit regularly decreased over time in storage in all treatments in both years $(p \leq 0.05)$ (Table 1 , Figure 5 e). This decrease could have resulted from using organic acids as essential substrates in respiration and energy metabolism of the fruit [41]. Titratable acidity content in quince fruit significantly changed, based on postharvest treatments $(p \leq 0.05)$. In the first year, 1-MCP-2-treated fruits had a higher level of titratable acidity during the earlier storage period, while similar acidity levels were observed in all groups in the second year. However, the controls exhibited lower levels of acidity in both years. The 1-MCP-2 and heat-treated groups, e.g., HT-1 and HT-2, on average showed higher acidity levels $(p \leq 0.05)$ (Table 1, Figure $5 f)$. Rather than 1 -MCP-1, hot water treatments and 1-MCP-2 seemed to help in maintaining titratable acidity levels by slowing down the loss in acidity during a storage period of 6 months.

\subsection{Weight Loss and Sensory Expert Analyses}

Due to continued respiration and lenticular transpiration, the weight loss in quince fruit inevitably increased during long-term storage in both years $(p \leq 0.05)$ (Table 1$)$. The increase in control fruits was highest in the first $(1.82 \%)$ and in the second $(1.78 \%)$ year (Figure $6 \mathrm{a}, \mathrm{b}$ ). However, the weight loss data observed in the 1-MCP-1 group were higher than controls during the last months of storage period in the second year. In terms of the significant effects of the postharvest treatments, HT-1 (1.24\%), HT-2 (1.21\%) and 1MCP-2 $(1.15 \%)$ treatments significantly delayed the increase in weight loss $(p \leq 0.05)$ (Figure 6b). The lower weight loss data in heat-treated fruits could have resulted from the softening of wax in the peel and filling of cracks on the peel, and the inhibitive effects of heat treatments, as expressed in a number of studies [21,22,39].

Sensory expert analyses demonstrated that the quince fruits were capable of maintaining their sensory traits without any postharvest treatment for a month during cold storage period. However, sensory evaluation scores significantly reduced in all groups throughout the rest of the storage period ( $p \leq 0.05$ ) (Table 1, Figure 6c). 1-MCP-2 and hot-water-treated fruit had the highest sensory expert scores (Figure 6d). However, 1-MCP-2 treatments resulted in lower scores at the end of 6 months in both years, and the scores were near to controls (Figure 6b,c). In this context, fruit in the HT-1 group exhibited the highest scores in both years. The panelists mostly mentioned the lack of aroma in 1-MCP-treated fruits. Evidently, the heat treatments helped in maintaining the sensory traits of quince fruit better than 1-MCP-2, even if 1-MCP treatment could alleviate the overall consumer preference in climacteric fruit $[17,20]$.

\subsection{Sugars, Organic Acids and Phenolic Profile}

Individual sugars in quince fruit significantly decreased after an increase during the first 3 months. The effect of postharvest treatments changed, based on the years. The storage period was the major factor affecting sugar levels of fruit in both years $(p \leq 0.05)$ (Table 2). The treatments significantly affected only the sorbitol content of the fruit in both years. The controls, HT-2 and 1-MCP-2 treatments in the first year and only controls in the second year caused higher levels of sorbitol content in fruit tissue. In the first year, the lowest glucose + galactose content was in the 1-MCP-2 treatment. The fruit in HT-2 and 1-MCP-1 groups had significantly higher sucrose content in the second year. These results 
comply with a scarce effect of the postharvest treatments on individual sugars in fruit tissue. In another study, neutral sugar residues were similar in both heated and non-heated apple fruits, but heat-treated fruits had a sweeter taste [42,43].

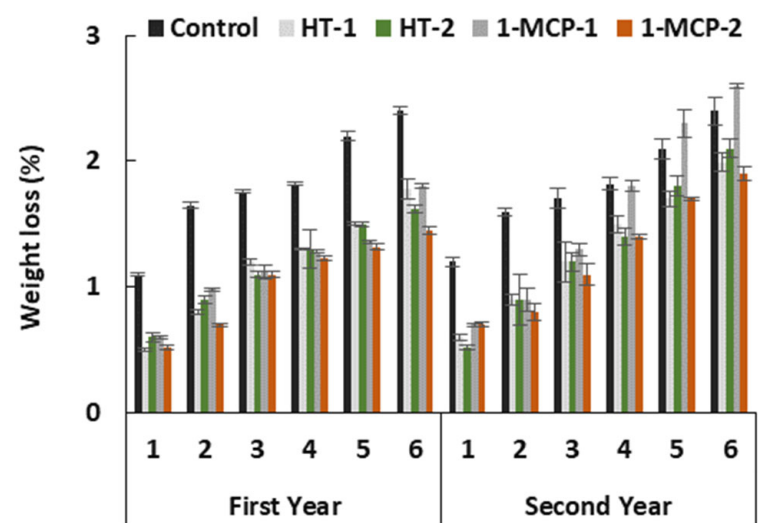

(a)

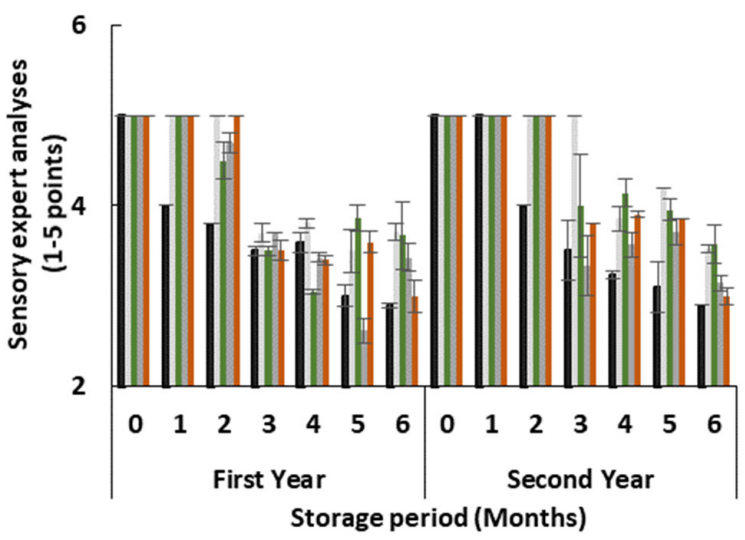

(c)

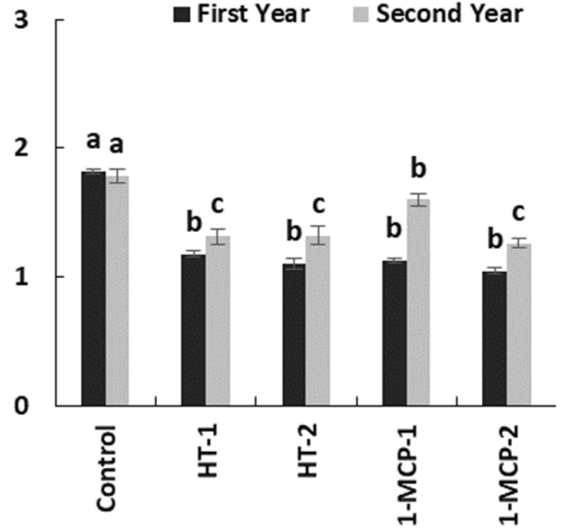

(b)

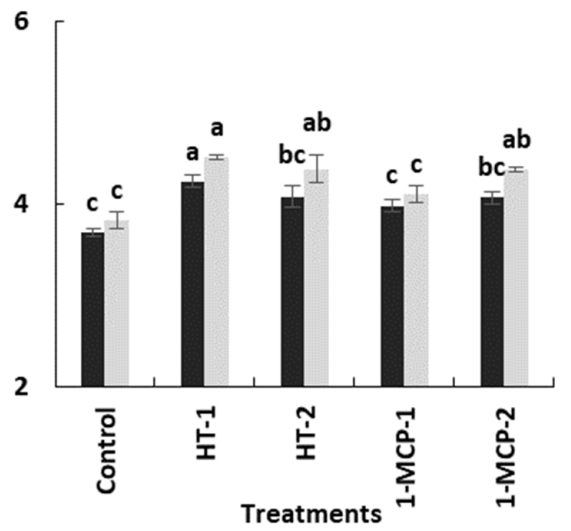

(d)

Figure 6. The effect of the storage period of 6 months at $0 \pm 1{ }^{\circ} \mathrm{C}$ temperature, $85-90 \%$ relative humidity and regular air conditions $(\mathbf{a}, \mathbf{c})$; and the effect of different postharvest treatments $(\mathbf{b}, \mathbf{d})$ on weight loss and sensory expert analyses of quince fruit during long-term cold storage. Controlwithout postharvest treatment; HT-1-Hot water treatment at $50 \pm 1{ }^{\circ} \mathrm{C}$ for $3 \mathrm{~min}$; HT-2-Hot water treatment at $50 \pm 1{ }^{\circ} \mathrm{C}$ for $5 \mathrm{~min}$; 1-MCP-1-300 ppb 1-methylcyclopropane (1-MCP) treatment at $12{ }^{\circ} \mathrm{C}$ for $20 \mathrm{~h}$; 1-MCP-2-1000 ppb 1-MCP treatment at $12{ }^{\circ} \mathrm{C}$ for $20 \mathrm{~h}$. Vertical lines are the standard error of means. Different letters are significantly different, according to Tukey test, at $p \leq 0.05$ significance level.

The individual organic acids, other than citric acid, significantly reduced during the storage period ( $p \leq 0.05$ ) (Table 2 ). In quince fruit, malic acid is the dominant organic acid $[4,5]$ and is principally responsible for fruit taste [30]. Fruit in heat and 1-MCP-2treated groups showed a higher level of malic acid content. It means that these treatments can delay the loss in malic acid, as mentioned in other studies $[20,35,39,44]$.

In our study, the major phenolic compound in fruit was 5-caffeoylquinic acid, followed by 3-caffeoylquinic acid, 4-caffeoylquinic acid and rutin (Table 3). Even if individual phenolics gradually decreased over time in the storage period, the reduction was significant for only 5-caffeoylquinic acid and 4-caffeoylquinic acid ( $p \leq 0.05)$. The same decreasing trend, both in phenolic compounds and in total antioxidant activity and total flavonoids, was reported in quince fruit during a long-term storage period [9,37]. In this study, HT-1 $\left(2165.59 \mathrm{mg} \cdot \mathrm{kg}^{-1}\right.$ fresh weight $\left.(\mathrm{FW})\right)$ followed by 1-MCP-2 $\left(2094.32 \mathrm{mg} \cdot \mathrm{kg}^{-1} \mathrm{FW}\right)$ and HT-2 (2007.34 mg. $\left.\mathrm{kg}^{-1} \mathrm{FW}\right)$ significantly delayed the loss in levels of 5-caffeoylquinic acid 
in the first year. However, similar regular effect of postharvest treatments was not observed in the second year.

Table 2. The effect of different postharvest treatments on individual sugar and organic acid contents of quince fruit.

\begin{tabular}{|c|c|c|c|c|c|}
\hline \multirow{2}{*}{ Years } & \multicolumn{5}{|c|}{ Sugars (mg.100 $\mathrm{g}^{-1}$ Fresh Weight (FW)) } \\
\hline & Treatments $^{1}$ & Sucrose & Glucose + Galactose & Fructose & Sorbitol \\
\hline \multirow{9}{*}{$\begin{array}{l}\text { First } \\
\text { Year }\end{array}$} & Control & $878.23 \pm 80.90 \mathrm{~ns}$ & $2278.37 \pm 102.04 \mathrm{a}^{2}$ & $4564.41 \pm 195.44 \mathrm{~ns}$ & $891.70 \pm 85.60 \mathrm{ab}$ \\
\hline & HT-1 & $944.86 \pm 43.01 \mathrm{~ns}$ & $2305.36 \pm 100.27 \mathrm{a}$ & $4368.51 \pm 235.37 \mathrm{~ns}$ & $853.30 \pm 43.57 b$ \\
\hline & HT-2 & $921.16 \pm 53.50 \mathrm{~ns}$ & $2417.93 \pm 123.57 \mathrm{a}$ & $4393.49 \pm 207.95 \mathrm{~ns}$ & $990.93 \pm 55.75$ a \\
\hline & 1-MCP-1 & $900.04 \pm 45.79 \mathrm{~ns}$ & $2234.79 \pm 86.62 \mathrm{ab}$ & $4500.14 \pm 180.60 \mathrm{~ns}$ & $859.63 \pm 54.14 b$ \\
\hline & 1-MCP-2 & $870.44 \pm 34.76 \mathrm{~ns}$ & $2054.26 \pm 89.75 c$ & $4311.57 \pm 175.16 \mathrm{~ns}$ & $886.14 \pm 69.41 \mathrm{ab}$ \\
\hline & \multicolumn{5}{|c|}{ Significance of influence $(p)$} \\
\hline & $\mathrm{SP}^{1}$ & $* * * 2$ & $* * *$ & $* *$ & $* * *$ \\
\hline & Ts & ns & $* * *$ & ns & $* *$ \\
\hline & $\mathrm{SP} \times \mathrm{Ts}$ & $* *$ & $* * *$ & ns & $* * *$ \\
\hline \multirow{11}{*}{$\begin{array}{l}\text { Second } \\
\text { Year }\end{array}$} & Control & $583.00 \pm 94.80 c$ & $1257.43 \pm 97.74 \mathrm{~ns}$ & $3927.99 \pm 231.31 \mathrm{~ns}$ & $1067.99 \pm 97.80 \mathrm{a}$ \\
\hline & HT-1 & $671.59 \pm 38.04 b$ & $1244.57 \pm 36.95 \mathrm{~ns}$ & $3937.76 \pm 151.90 \mathrm{~ns}$ & $873.73 \pm 49.25 \mathrm{~b}$ \\
\hline & HT-2 & $696.57 \pm 35.55 \mathrm{a}$ & $1185.83 \pm 32.09 \mathrm{~ns}$ & $3879.17 \pm 117.74 \mathrm{~ns}$ & $833.30 \pm 45.12 b$ \\
\hline & 1-MCP-1 & $693.24 \pm 42.16$ a & $1239.84 \pm 37.13 \mathrm{~ns}$ & $3844.50 \pm 119.30 \mathrm{~ns}$ & $945.44 \pm 39.92 b$ \\
\hline & $1-\mathrm{MCP}-2$ & $666.91 \pm 41.08 \mathrm{~b}$ & $1226.89 \pm 51.27 \mathrm{~ns}$ & $3988.57 \pm 150.71 \mathrm{~ns}$ & $888.26 \pm 65.34 b$ \\
\hline & \multicolumn{5}{|c|}{ Significance of influence $(p)$} \\
\hline & SP & $* * *$ & ns & $* *$ & * \\
\hline & Ts & $* * *$ & ns & ns & $* * *$ \\
\hline & $\mathrm{SP} \times \mathrm{Ts}$ & $* * *$ & ns & ns & ns \\
\hline & \multicolumn{5}{|c|}{ Organic Acids $\left(\mathrm{mg} \cdot \mathrm{kg}^{-1} \mathrm{FW}\right)$} \\
\hline & Treatments & Oxalic Acid & Citric Acid & Malic Acid & Succinic Acid \\
\hline \multirow{9}{*}{ First Year } & Control & $58.71 \pm 3.88 \mathrm{ab}$ & $27.53 \pm 2.59 c$ & $5925.00 \pm 256.08 \mathrm{~b}$ & $2042.71 \pm 88.55 \mathrm{a}$ \\
\hline & HT-1 & $63.75 \pm 5.44 \mathrm{ab}$ & $32.42 \pm 1.93 \mathrm{ab}$ & $6556.14 \pm 340.67 a$ & $1856.86 \pm 175.50 \mathrm{ab}$ \\
\hline & HT-2 & $64.92 \pm 2.10 \mathrm{a}$ & $31.56 \pm 1.57 \mathrm{ab}$ & $6738.91 \pm 336.38 \mathrm{a}$ & $1602.37 \pm 183.33 b$ \\
\hline & 1-MCP-1 & $57.31 \pm 2.61 \mathrm{ab}$ & $28.81 \pm 2.53 \mathrm{bc}$ & $5759.71 \pm 208.65 b$ & $1721.00 \pm 117.30 \mathrm{~b}$ \\
\hline & 1-MCP-2 & $55.35 \pm 3.76 \mathrm{~b}$ & $34.45 \pm 2.53 \mathrm{a}$ & $6217.14 \pm 215.48 \mathrm{ab}$ & $1783.56 \pm 85.00 \mathrm{ab}$ \\
\hline & \multicolumn{5}{|c|}{ Significance of influence $(p)$} \\
\hline & SP & $* * *$ & $*$ & $* * *$ & $* * *$ \\
\hline & Ts & $*$ & $* * *$ & $* * *$ & $* * *$ \\
\hline & $\mathrm{SP} \times \mathrm{Ts}$ & ns & $* *$ & $* * *$ & $*$ \\
\hline \multirow{9}{*}{$\begin{array}{l}\text { Second } \\
\text { Year }\end{array}$} & Control & $110.42 \pm 11.88 \mathrm{a}$ & $27.99 \pm 5.56 \mathrm{~ns}$ & $6033.57 \pm 540.43 b$ & $1490.96 \pm 148.61 \mathrm{a}$ \\
\hline & HT-1 & $95.54 \pm 10.13 \mathrm{ab}$ & $29.88 \pm 4.01 \mathrm{~ns}$ & $6733.14 \pm 371.00 \mathrm{ab}$ & $1393.03 \pm 184.74 \mathrm{a}$ \\
\hline & HT-2 & $84.47 \pm 8.46 \mathrm{~b}$ & $27.81 \pm 2.71 \mathrm{~ns}$ & $6589.44 \pm 333.49 \mathrm{ab}$ & $1424.21 \pm 148.10 \mathrm{a}$ \\
\hline & 1-MCP-1 & $98.45 \pm 9.34 \mathrm{ab}$ & $25.00 \pm 4.31 \mathrm{~ns}$ & $6643.71 \pm 575.86 \mathrm{ab}$ & $1623.86 \pm 178.00 \mathrm{a}$ \\
\hline & $1-\mathrm{MCP}-2$ & $101.62 \pm 8.89 \mathrm{a}$ & $31.26 \pm 3.41 \mathrm{~ns}$ & $7034.29 \pm 485.29 a$ & $1653.14 \pm 171.28 \mathrm{a}$ \\
\hline & \multicolumn{5}{|c|}{ Significance of influence $(p)$} \\
\hline & SP & $* * *$ & ns & $* * *$ & $* * *$ \\
\hline & Ts & $* * *$ & ns & $*$ & $* * *$ \\
\hline & $\mathrm{SP} \times \mathrm{Ts}$ & ns & ns & ns & ns \\
\hline & & $\begin{array}{l}{ }^{1} \text { Control-without posth } \\
\text { treatment at } 50 \pm 1{ }^{\circ} \mathrm{C} \text { for } \\
1 \text {-MCP-2-1000 } \mathrm{ppb} 1-\mathrm{MC} \\
{ }^{2} \text { Data were presented as } \\
\text { Tukey test, at } p \leq 0.05 \mathrm{sig} \\
\text { respectively; ns-not sign }\end{array}$ & $\begin{array}{l}\text { st treatment; HT-1-Hot } \\
\text { in; } 1 \text {-MCP- } 1-300 \text { ppb } 1-n \\
\text { eatment at } 12{ }^{\circ} \mathrm{C} \text { for } 20 \mathrm{~h} \text {; } \\
\pm \text { standard error of mear } \\
\text { ance level; }{ }^{*}, * * \text {, and }{ }^{* * *}\end{array}$ & $\begin{array}{l}\text { treatment at } 50 \pm 1{ }^{\circ} \mathrm{C} \\
\text { ylcyclopropane }(1-\mathrm{MCP}) \\
\text {-storage period, harvest } \\
\text { fferent letters are signific } \\
\text { ficant at } p \leq 0.05,0.01 \text { ar }\end{array}$ & $\begin{array}{l}3 \mathrm{~min} \text {; HT- }- \text { - Hot wate } \\
\text { eatment at } 12{ }^{\circ} \mathrm{C} \text { for } 20 \mathrm{~h} \\
6 \text { months; Ts-treatments } \\
\text { tly different, according to } \\
0.001 \text { significance levels }\end{array}$ \\
\hline
\end{tabular}


Table 3. The effect of different postharvest treatments on phenolic compounds $\left(\mathrm{mg} \cdot \mathrm{kg}^{-1}\right.$ fresh weight $(\mathrm{FW}))$ of quince fruit.

\begin{tabular}{|c|c|c|c|c|c|}
\hline Years & Treatments ${ }^{1}$ & $\begin{array}{c}5- \\
\text { Caffeoylquinic } \\
\text { Acid }\end{array}$ & $\begin{array}{c}3- \\
\text { Caffeoylquinic } \\
\text { Acid }\end{array}$ & $\begin{array}{c}4- \\
\text { Caffeoylquinic } \\
\text { Acid }\end{array}$ & Rutin \\
\hline \multirow{9}{*}{ First Year } & Control & $1926.87 \pm 138.29 c^{2}$ & $697.47 \pm 85.79 \mathrm{~ns}$ & $208.14 \pm 24.07 \mathrm{~ns}$ & $139.06 \pm 28.59 \mathrm{~ns}$ \\
\hline & HT-1 & $2165.59 \pm 208.44 \mathrm{a}$ & $714.31 \pm 88.75 \mathrm{~ns}$ & $227.63 \pm 9.87 \mathrm{~ns}$ & $168.51 \pm 31.98 \mathrm{~ns}$ \\
\hline & HT-2 & $2007.34 \pm 179.76 \mathrm{~b}$ & $739.44 \pm 98.48 \mathrm{~ns}$ & $232.98 \pm 18.97 \mathrm{~ns}$ & $172.45 \pm 15.80 \mathrm{~ns}$ \\
\hline & 1-MCP-1 & $1627.19 \pm 210.46 \mathrm{~d}$ & $552.96 \pm 104.19 \mathrm{~ns}$ & $176.39 \pm 15.27 \mathrm{~ns}$ & $151.43 \pm 9.38 \mathrm{~ns}$ \\
\hline & 1-MCP-2 & $2094.32 \pm 222.13 b$ & $847.83 \pm 102.66 \mathrm{~ns}$ & $233.51 \pm 19.83 \mathrm{~ns}$ & $180.76 \pm 23.74 \mathrm{~ns}$ \\
\hline & \multicolumn{5}{|c|}{ Significance of influence $(p)$} \\
\hline & $\mathrm{SP}$ & $* * *$ & ns & * & ns \\
\hline & Ts & $*$ & ns & ns & ns \\
\hline & $\mathrm{SP} \times \mathrm{Ts}$ & * & ns & ns & ns \\
\hline \multirow{9}{*}{ Second Year } & Control & $1741.35 \pm 122.86 \mathrm{~ns}$ & $870.28 \pm 87.56 \mathrm{~ns}$ & $208.43 \pm 21.27 \mathrm{~ns}$ & $129.63 \pm 21.83 \mathrm{~ns}$ \\
\hline & HT-1 & $2007.71 \pm 160.29 \mathrm{~ns}$ & $738.79 \pm 95.42 \mathrm{~ns}$ & $217.34 \pm 21.13 \mathrm{~ns}$ & $145.47 \pm 21.31 \mathrm{~ns}$ \\
\hline & HT-2 & $1847.58 \pm 150.67 \mathrm{~ns}$ & $799.13 \pm 112.46 \mathrm{~ns}$ & $213.41 \pm 21.01 \mathrm{~ns}$ & $140.97 \pm 16.02 \mathrm{~ns}$ \\
\hline & 1-MCP-1 & $1458.91 \pm 122.73 \mathrm{~ns}$ & $780.76 \pm 105.75 \mathrm{~ns}$ & $199.11 \pm 25.08 \mathrm{~ns}$ & $130.71 \pm 21.30 \mathrm{~ns}$ \\
\hline & 1-MCP-2 & $1947.03 \pm 175.41 \mathrm{~ns}$ & $780.60 \pm 85.72 \mathrm{~ns}$ & $198.29 \pm 23.46 \mathrm{~ns}$ & $113.07 \pm 23.74 \mathrm{~ns}$ \\
\hline & \multicolumn{5}{|c|}{ Significance of influence $(p)$} \\
\hline & SP & ns & ns & $* *$ & ns \\
\hline & Ts & ns & ns & ns & ns \\
\hline & $\mathrm{SP} \times \mathrm{Ts}$ & ns & ns & ns & ns \\
\hline
\end{tabular}

${ }^{1}$ Control-without postharvest treatment; HT-1-Hot water treatment at $50 \pm 1{ }^{\circ} \mathrm{C}$ for 3 min; HT-2-Hot water treatment at $50 \pm 1{ }^{\circ} \mathrm{C}$ for $5 \mathrm{~min}$; $1-\mathrm{MCP}-1-300 \mathrm{ppb}$ 1-methylcyclopropane (1-MCP) treatment at $12{ }^{\circ} \mathrm{C}$ for $20 \mathrm{~h}$; 1-MCP-2-1000 ppb 1-MCP treatment at $12{ }^{\circ} \mathrm{C}$ for $20 \mathrm{~h}$; SP-storage period, harvest +6 months; Ts-treatments 2 Data were presented as mean \pm standard error of mean; Different letters are significantly different, according to Tukey test, at $p \leq 0.05$ error level; ${ }^{*},{ }^{* *}$, and ${ }^{* * *}$ - significant at $p \leq 0.05,0.01$, and 0.001 significance levels, respectively; ns-not significant at $p>0.05$.

\subsection{Vitamin C}

Vitamin C content of quince fruits was significantly decreased in all groups and both years $(p \leq 0.05)$ (Table 1, Figure 7a). Previous studies reported similar results [35,37]. Even low-temperature storage conditions did not prevent the loss of vitamin $C$ in control group, and the fruits exhibited a more than 13 -fold decline in vitamin $C$ content. The lowest loss in vitamin $C$ content was observed in the 1-MCP-2 group (Figure $7 \mathrm{~b}$ ). Vitamin $C$ content was significantly highest in the $1-\mathrm{MCP}-2$ group $\left(53.18 \mathrm{mg} \cdot \mathrm{kg}^{-1}\right.$ fresh weight (FW) and $\left.51.13 \mathrm{mg} \cdot \mathrm{kg}^{-1} \mathrm{FW}\right)$ followed by the HT-1 $\left(46.53 \mathrm{mg} \cdot \mathrm{kg}^{-1} \mathrm{FW}\right.$ and $\left.34.46 \mathrm{mg} \cdot \mathrm{kg}^{-1} \mathrm{FW}\right)$, 1-MCP-1 (18.67 mg.kg ${ }^{-1} \mathrm{FW}$ and $\left.13.11 \mathrm{mg} \cdot \mathrm{kg}^{-1} \mathrm{FW}\right)$ and HT-2 $\left(10.41 \mathrm{mg} \cdot \mathrm{kg}^{-1} \mathrm{FW}\right.$ and $\left.5.41 \mathrm{mg} \cdot \mathrm{kg}^{-1} \mathrm{FW}\right)$ groups in the first and the second year, respectively. Contrary to our results, it has been reported that, for climacteric fruit species in the Rosaceae family, the efficacy of 1-MCP treatment in maintaining vitamin C content during the cold storage period was less than in other fruit attributes [45]. However, an affirmative effect of heat treatments on maintaining vitamin $C$ values in some horticultural products was explained in detail [38]. 


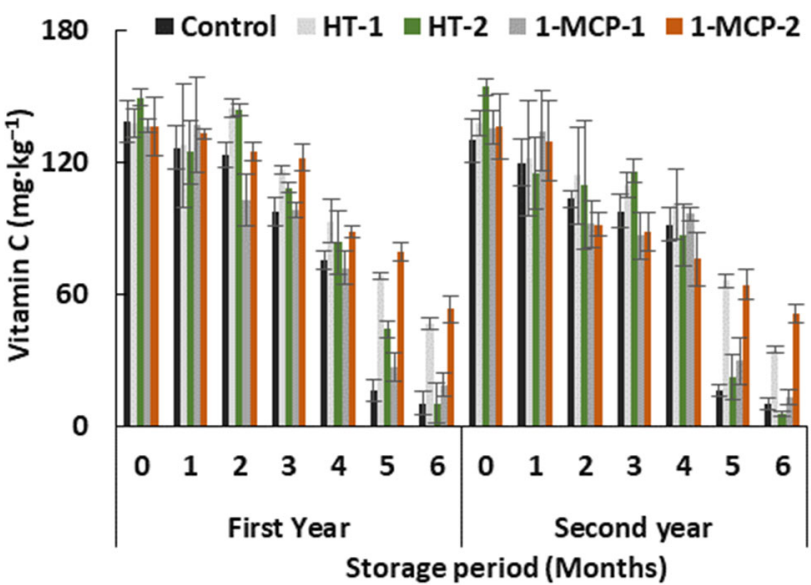

(a)

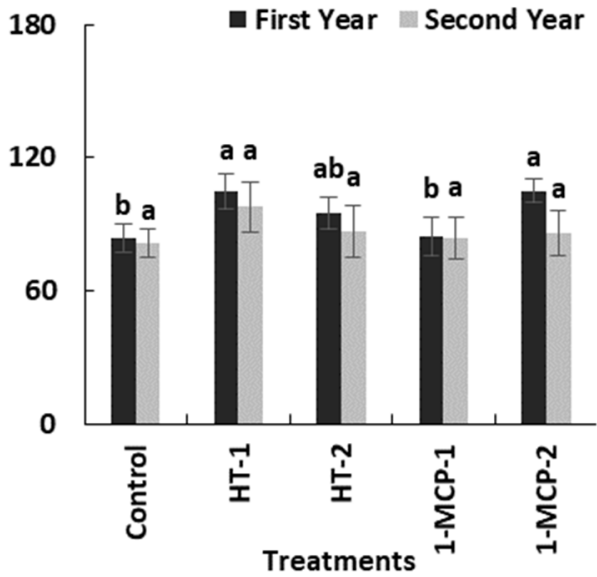

(b)

Figure 7. The effect of storage period of 6 months at $0 \pm 1{ }^{\circ} \mathrm{C}$ temperature, $85-90 \%$ relative humidity and regular air conditions (a); and the effect of different postharvest treatments (b) on vitamin $\mathrm{C}$ content of quince fruit during long-term cold storage. Control—without postharvest treatment; HT-1-Hot water treatment at $50 \pm 1{ }^{\circ} \mathrm{C}$ for $3 \mathrm{~min}$; HT-2- Hot water treatment at $50 \pm 1{ }^{\circ} \mathrm{C}$ for $5 \mathrm{~min}$; 1-MCP-1-300 ppb 1-methylcyclopropane (1-MCP) treatment at $12{ }^{\circ} \mathrm{C}$ for $20 \mathrm{~h}$; 1 -MCP-2-1000 ppb 1 -MCP treatment at $12{ }^{\circ} \mathrm{C}$ for $20 \mathrm{~h}$. Vertical lines are the standard error of means. Different letters are significantly different, according to Tukey test, at $p \leq 0.05$ significance level; ns-not significant at $p \leq 0.05$.

\section{Conclusions}

This research was conducted on 'Eşme' quince fruit to determine potential usage of hot water treatments at $50 \pm 1{ }^{\circ} \mathrm{C}$ for different durations. Our findings showed that hot water and $1000 \mathrm{ppb} 1$-methylcyclopropane (1-MCP) treatments were effective in maintaining some fruit quality traits. Lower flesh browning incidence with higher flesh $L^{*}$ data in fruits caused by these treatments demonstrated that they helped to improve the tolerance of fruit to chilling injury. Moreover, these treatments enabled the maintenance of the nutritional value of fresh quince fruits with respect to higher levels of 5-caffeoylquinic acid, malic acid and vitamin $C$ during the cold storage period. Similar scores in sensory expert analyses observed in hot-water-treated groups can be an indication of the commercial potential of these treatments in quince fruit. Given that hot water treatments are chemicalfree applications with no harmful effect on either human health or the environment, the commercial selection of hot water treatments for maintaining quality parameters in quince fruit during cold storage period at $0 \pm 1{ }^{\circ} \mathrm{C}$ and the marketing process will be driven by consumer demand.

The ease of application of hot water treatments and 1-MCP-based technology is an important factor in transferring them into practice. Today, 1-MCP-based technology can be applied in gaseous form after harvest and/or aqueous form before the harvest period. However, there are some difficulties in the application of gaseous 1-MCP treatment [20]. A gas-tight room is required for maintaining the optimum 1-MCP concentration for the entire treatment period. The efficacy and uniformity of 1-MCP treatment is compromised by the presence of non-target materials, e.g., wooden and cardboard bins and bin-liner material, as these materials can decrease 1-MCP concentration by easily absorbing it. Stack design in a cold storage room is important for proper distribution of 1-MCP within the product as well. Additionally, the stability of the molecule, the contact of 1-MCP with all crops on the tree during treatment and application time are important factors in the use of the aqueous 1-MCP form.

Hot water treatments can be applied via hot water rinsing and brushing technology that can clean the product during application [21]. However, the extra energy requirements can limit the usage of this technology, since a drying period is essential after hot water 
treatments. Consequently, the selection, application and integration of these technologies into postharvest systems for maintaining quality in quince fruit during a long-term storage period can be arranged depending on consumer preferences in the future.

Author Contributions: Conceptualization, N.T.G.; planning and methodology, N.T.G. and E.S.P.; physical and chemical statistical analyses, N.T.G.; chromatographic analyses, N.T.G. and E.S.P.; writing, N.T.G. and E.S.P. All authors have read and agreed to the published version of the manuscript.

Funding: This research was funded by The Scientific and Technological Research Council of Turkey (TÜBİTAK), grant number $106 \mathrm{O} 120$.

Institutional Review Board Statement: Not applicable.

Informed Consent Statement: Not applicable.

Data Availability Statement: Publicly available quince production datasets from Food and Agriculture Organization of the United Nations were presented in this study. These data can be found here: https: / www.fao.org/faostat/en/\#data/QCL, accessed on 11 October 2021. Publicly available Biopesticide Registration Action Document, 1- Methylcyclopropene (PC Code 224459) from US Environmental Protection Agency (US EPA) was presented in this study. This document can be found here: https: / / www3.epa.gov/pesticides/chem_search/reg_actions/registration/decision_PC-22 4459_30-May-08.pdf, accessed on 9 September 2021.

Conflicts of Interest: The authors declare no conflict of interest.

\section{References}

1. Food and Agriculture Organization of the United Nations. Available online: https://www.fao.org/faostat/en/\#data/QCL (accessed on 11 October 2021).

2. Khoubnasabjafari1, M.; Jouyban, A. A review of phytochemistry and bioactivity of quince (Cydonia oblonga Mill.). J. Med. Plants Res. 2011, 5, 3577-3594. [CrossRef]

3. Muzykiewicz, A.; Zielonka Brzezicka, J.; Klimowicz, A. Quince (Cydonia oblonga Mill.) as a useful source of antioxidantsAntioxidant activity evaluation. Herba Pol. 2018, 64, 23-33. [CrossRef]

4. Tuna Gunes, N. Changes in ethylene production in quince (Cydonia vulgaris L.) and the use of ethylene to predict harvest maturity. Eur. J. Hortic. Sci. 2003, 68, 212-221.

5. Silva, B.M.; Andrade, P.B.; Mendes, G.C.; Seabra, R.M.; Ferreira, M.A. Study of organic acids composition of quince (Cydonia oblonga Miller) fruit and jam. J. Agric. Food Chem. 2002, 50, 2313-2317. [CrossRef]

6. Forni, E.; Penci, M.; Polesello, A. A Preliminary characterization of some pectins from quince fruit (Cydonia oblonga Mill.) and prickly pear (Opuntia ficus indica) peel. Carbohydr. Polym. 1994, 23, 231-234. [CrossRef]

7. Silva, B.M.; Casal, S.; Andrade, P.B.; Seabra, R.M.; Oliviera, M.B.P.P.; Ferreira, M.A. Free amino acid composition of quince (Cydonia oblonga Miller) fruit (pulp and peel) and jam. J. Agric. Food Chem. 2004, 52, 1201-1206. [CrossRef] [PubMed]

8. Silva, B.M.; Andrade, P.B.; Ferreres, F.; Dominques, A.L.; Seabra, R.M.; Ferreira, M.A. Phenolic profile of quince fruit (Cydonia oblonga Miller) (pulp and peel). J. Agric. Food Chem. 2002, 50, 4615-4618. [CrossRef] [PubMed]

9. Hamauzu, Y.; Yasui, H.; Inno, T.; Kume, C.; Omanyuda, M. Phenolic profile, antioxidant property, and anti-influenza viral activity of Chinese quince (Pseudocydonia sinensis Schneid.), quince (Cydonia oblonga Mill.), and apple (Malus domestica Mill.) fruits. J. Agric. Food Chem. 2005, 53, 928-934. [CrossRef]

10. Gunes, N.T.; Poyrazoglu, E.S. Evaluation of some quince (Cydonia oblonga Mill.) cultivars in terms of jam processing. Acta Hortic. 2020, 1292, 73-78. [CrossRef]

11. Tuna Gunes, N.; Dumanoglu, H. Some fruit attributes of quince (Cydonia oblonga) based on genotypes during the pre-harvest period. N. Z. J. Crop Hortic. Sci. 2005, 33, 211-217. [CrossRef]

12. Radovicć, A.; Milatovicć, D.; Nikolicć, D.; Đurovicć, D.; Đorđevicć, B.; Bakicć, I. Changes in fruit quality of quinces during cold storage. Acta Hortic. 2020, 1289, 73-77. [CrossRef]

13. Gunes, N.T. Ripening regulation during storage in quince (Cydonia oblonga Mill.) fruit. Acta Hortic. 2008, 796, 191-196. [CrossRef]

14. Yahia, E.M. Postharvest Technology of Perishable Horticultural Commodities; Woodhead Publishing: New Delhi, India, 2019; 719p.

15. Sisler, E.C.; Blankenship, S.M. Methods of Counteracting an Ethylene Response in Plants. U.S. Patent 5,518,988, 21 May 1996.

16. US Environmental Protection Agency (US EPA) Biopesticide Registration Action Document. 1-Methylcyclopropene (PC Code 224459). Available online: https://www3.epa.gov/pesticides/chem_search/reg_actions/registration/decision_PC-224459_30May-08.pdf (accessed on 9 September 2021).

17. Gunes, N.T. Effect of 1-MCP and different ecological conditions on postharvest quality of 'Eşme' quince fruit during long term storage. Acta Hortic. 2010, 877, 387-394. [CrossRef]

18. Sakaldaş, M.; Kaynaş, K.; Dombaz, Y. Effects of 1-methylcyclopropene on fruit quality and biochemical properties of 'Esme' quince cultivar during long term storage. Acta Hortic. 2010, 876, 259-265. [CrossRef] 
19. Nanos, G.D.; Mpezou, A.; Georoudaki, T. Effects of 1-MCP and storage temperature on quince fruit quality. Acta Hortic. 2015, 1079, 453-458. [CrossRef]

20. Watkins, C.B. Advances in the use of 1-MCP. In Advances in Postharvest Fruit and Vegetable Technology; Wills, R.B.H., Golding, J.B., Eds.; CRC Press: Boca Raton, FL, USA, 2015; pp. 117-146.

21. Fallik, E.; Alkalai-Tuvia, S.; Chalupowicz, D. Hot water rinsing and brushing of fresh produce as an alternative to chemical treatment after harvest-The story behind the technology. Agronomy 2021, 11, 1653. [CrossRef]

22. Fallik, E.; Ilic', Z. Control of postharvest decay of fresh produce by heat treatments: The risks and benefits. In Postharvest Pathology of Fresh Horticultural Produce; Palou, L., Smilanick, J.L., Eds.; CRC Press: Boca Raton, FL, USA, 2020; pp. 521-538.

23. Yurdugül, S. Preservation of quinces by the combination of an edible coating material, Semperfresh, ascorbic acid and cold storage. Eur. Food Res. Technol. 2005, 220, 579-586. [CrossRef]

24. Hussain, P.R.; Rather, S.A.; Suradkar, P.P.; Ayob, O. Gamma irradiation treatment of quince fruit (Cydonia oblonga Mill.): Effect on post-harvest retention of storage quality and inhibition of fungal decay. J. Radiat. Res. Appl. Sci. 2019, 12, 118-131. [CrossRef]

25. Klein, J.; Lurie, S. Prestorage heat treatment as a means of improving poststorage quality of apples. J. Am. Soc. Hortic. Sci. 1990, 115, 265-269. [CrossRef]

26. Banks, N.H.; Cleland, D.J.; Cameron, A.C.; Beaudry, R.M.; Kader, A.A. Proposal for a rationalized system of units for postharvest research in gas exchange. HortScience 1995, 30, 1129-1131. [CrossRef]

27. McGuire, R.G. Reporting of objective color measurements. HortScience 1992, 27, 1254-1255. [CrossRef]

28. Manganaris, G.A.; Vasilakakis, M.; Diamantidis, G.; Mignami., I. Cell wall physicochemical aspects of peach fruit related to internal breakdown symptoms. Postharvest Biol. Technol. 2006, 39, 69-74. [CrossRef]

29. Gálvez-Lòpez, D.; Laurens, F.; Devaux, M.F.; Lahaye, M. Texture analysis in an apple progeny through instrumental, sensory and histological phenotyping. Euphytica 2012, 185, 171-183. [CrossRef]

30. Tuna-Gunes, N.; Koksal, A.I. Relationships between some fruit characteristics and sensory evaluation in quince (Cydonia oblonga Mill.) fruits. Acta Hortic. 2007, 741, 125-133. [CrossRef]

31. Tuna Gunes, N.; Aygun, A.; San, B. Postharvest heat treatments for enhanced fruit quality during storage of early ripening European pear. Eur. J. Hortic. Sci. 2006, 71, 135-142.

32. Flores, P.; Hellín, P.; Fenoll, J. Determination of organic acids in fruits and vegetables by liquid chromatography with tandem-mass spectrometry. Food Chem. 2012, 132, 1049-1054. [CrossRef]

33. Arya, S.P.; Mahajan, M.; Jain, P. Non-spectrophotometric methods for the determination of Vitamin C. Anal. Chim. Acta 2000, 417, 1-14. [CrossRef]

34. Tuncel Hasçelik, H.; Şen, F. Research on the effects of harvest stage and 1-methylcyclopropene on postharvest quality of 'Eşme' quince fruit during long-term storage. Acta Hortic. 2020, 1275, 253-260. [CrossRef]

35. Gunes, N.T.; Dumanoglu, H.; Poyrazoglu, E.S. Use of 1-MCP for keeping postharvest quality of 'Ekmek' quince fruit. Acta Hortic. 2012, 934, 297-302. [CrossRef]

36. Tatari, M.; Mousavi, A. Impact of harvesting time and length of cold storage period on physiological and quality traits of four quince genotypes (Cydonia oblonga Mill.). J. Hortic. Res. 2017, 25, 67-79. [CrossRef]

37. Moradi, S.; Koushesh Saba, M.; Mozafari, A.A.; Abdollahi, H. Antioxidant bioactive compounds changes in fruit of quince genotypes over cold storage. J. Food Sci. 2016, 81, H1833-H1839. [CrossRef]

38. Fallik, E.; Ilić, Z. The influence of physical treatments on phytochemical changes in fresh produce after storage and marketing. Agronomy 2021, 11, 788. [CrossRef]

39. Yildiz, G.; Izli, G.; Aadil, R.M. Comparison of chemical, physical, and ultrasound treatments on the shelf life of fresh-cut quince fruit (Cydonia oblonga Mill.). J. Food Process. Preserv. 2020, 44, e14366. [CrossRef]

40. Moradi, S.; Saba, M.K.; Mozafari, A.A.; Abdollahi, H. Physical and biochemical changes of some Iranian quince (Cydonia oblonga Mill.) genotypes during cold storage. J. Agr. Sci. Tech. 2017, 19, 377-388.

41. Yi, M.; Kong, J.; Yu, Z. Effect of heat treatment on the quality and energy metabolism in "Golden Delicious" apple fruit. J. Food Biochem. 2021, 45, e13759. [CrossRef]

42. Klein, J.D.; Lurie, S.; Ben-Arie, R. Quality and cell wall components of 'Anna' and 'Granny Smith' apples treated with heat, calcium and ethylene. J. Am. Soc. Hortic. Sci. 1990, 115, 954-958. [CrossRef]

43. Lurie, S.; Nussinovitch, A. Compression characteristics, firmness, and texture perception of heat treated and un-heated apples. Intern. J. Food Sci. Technol. 1996, 31, 1-5. [CrossRef]

44. Gunes, N.T.; Poyrazoglu, E.S.; Dumanoglu, H. Preliminary results on some constitutional changes in 1-MCP treated quince (Cydonia oblonga Mill.) fruit during cold storage period. Acta Hortic. 2010, 858, 229-234. [CrossRef]

45. Zhang, J.; Ma, Y.; Dong, C.; Terry, L.A.; Watkins, C.B.; Yu, Z.; Chang, Z.-M. Meta-analysis of the effects of 1-methylcyclopropene (1-MCP) treatment on climacteric fruit ripening. Hortic. Res. 2020, 7, 208. [CrossRef] 